\title{
The meteorite of Barcelona (1704): history, discovery and classification
}

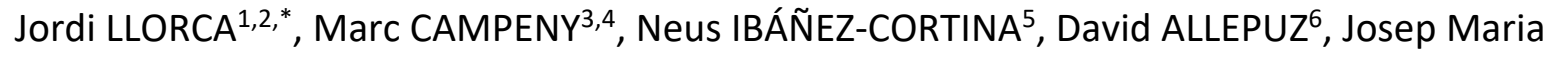 \\ CAMARASA ${ }^{7}$, Josep AURELL-GARRIDO ${ }^{8}$
}

${ }^{1}$ Institute of Energy Technologies, Department of Chemical Engineering and Barcelona Research Center in Multiscale Science and Engineering, Universitat Politècnica de Catalunya, EEBE, Eduard Maristany 10-14, E-08019 Barcelona, Catalonia, Spain.

${ }^{2}$ Institut d’Estudis Catalans, Carrer del Carme 47, E-08001 Barcelona, Catalonia, Spain.

${ }^{3}$ Museu de Ciències Naturals de Barcelona, Departament de Mineralogia, Passeig Picasso s/n, E-08003 Barcelona, Catalonia, Spain.

${ }^{4}$ Departament de Mineralogia, Petrologia I Geologia Aplicada, Universitat de Barcelona, Martí i Franquès s/n, E-08028 Barcelona, Catalonia, Spain.

${ }^{5}$ Botanic Institute of Barcelona (IBB, CSIC-ICUB), Passeig del Migdia s/n, E-08038 Barcelona, Catalonia, Spain.

${ }^{6}$ Sant Julià de Vilatorta Observatory, E-08514 Sant Julià de Vilatorta, Catalonia, Spain.

${ }^{7}$ Seminari d'Història de la Ciència Joan Francesc Bahí. Fundació Carl Faust. Passeig Carles Faust, 9. E-17300 Blanes, Catalonia, Spain.

8 Institut Català de Paleontologia Miquel Crusafont, Universitat Autònoma de Barcelona, Columnes s/n, Campus de la UAB, E-08193 Cerdanyola del Vallès, Catalonia, Spain.

*Corresponding author: jordi.Ilorca@upc.edu

\begin{abstract}
On Christmas Day 1704, at 17h (UT), a meteorite fell in Terrassa (about $25 \mathrm{~km} \mathrm{NW}$ of Barcelona). The meteorite fall was seen and heard by many people over an area of several hundred kilometers and it was recorded in several historical sources. In fact, it was interpreted as a divine sign and used for propaganda purposes during the War of the Spanish Succession. Although it was believed that meteorite fragments were never preserved, here we discuss the recent discovery of two fragments (49.8 and $33.7 \mathrm{~g}$ ) of the Barcelona meteorite in the Salvador Cabinet collection (Botanic Institute of Barcelona). They are very well preserved and partially covered by a fresh fusion crust, which suggests a prompt recovery, shortly after the fall. Analysis of the fragments has revealed that the Barcelona meteorite is a L6 ordinary chondrite. These fragments are among the oldest historical meteorites preserved in the world.
\end{abstract}

Keywords: Meteorite fall, historical meteorite, L chondrite. 


\section{Introduction}

Educated Europe, from the Renaissance to the Enlightenment, was suffused with passion for collecting antiques, paintings, sculptures, jewels, and a wide variety of objects that could be classed as "marvels" or "curiosities". For more than three centuries, the so-called cabinets were a privileged venue for developing natural history: the discipline which is the origin of the natural sciences of today. This is the case of the Salvador Cabinet, which has been preserved since 1938 in the Botanic Institute of Barcelona (a joint venture between the Spanish National Research Council (CSIC) and the Barcelona City Council), and managed by Museu de Ciències Naturals de Barcelona (MCNB). The Salvador family was a line of apothecaries settled in Barcelona from the early XVII to the mid-XIX centuries. They founded a valuable scientific library, a botanic garden and the most significant cabinet of curiosities and natural history in Catalonia at that time. Since the beginning of the $18^{\text {th }}$ century to the middle of the $19^{\text {th }}$ century the Salvador Cabinet was a must for all those interested in natural history, or simply curious people or scholars who passed through the city of Barcelona. In fact, it was the first museum open to the inhabitants of Barcelona, as mentioned by the city guides since 1797 (Camarasa 2018). Here we report that, among all the treasures, the Salvador Cabinet collection also preserved two fragments of the meteorite that fell in Terrassa (25 km NW of Barcelona) in 1704. This meteorite is known as the Barcelona meteorite. According to the Meteoritical Bulletin, there are only six official and classified meteorite falls older than the meteorite of Barcelona in the world: Nogata (Japan, 861), Ensisheim (France, 1492), Jalandhar (India, 1621), Minamino (Japan, 1632), Vago (Italy, 1668) and Sasagase (Japan, 1704).

The fall of the Barcelona meteorite was widely reported and cited (see a review of the bibliography in Llorca 2004 and Aragonés 2008), but until today preserved fragments of this meteorite were not known in any public or private institution. During the cataloging of the Salvador Cabinet, Aurell-Garrido (2015) and Aragonés (2015) pointed out the existence of two meteorite specimens in a glass jar accompanied by an old label. In the present work, we carry out the petrographic and geochemical description of the Barcelona meteorite and its corresponding classification as a L6 ordinary chondrite. We have also compiled, transcribed, and translated the most relevant historical documents and illustrations regarding the Barcelona meteorite fall, constituting a valuable example of how a meteorite fall was interpreted in the Modern Age as a bad omen and also as a divine sign. In the case of the 
Barcelona meteorite fall, it was also the origin of numerous predictions and superstitions related to the War of the Spanish Succession (1702-1714).

\section{The Barcelona meteorite fall ( $25^{\text {th }}$ December of 1704$)$}

\subsection{The fireball}

On Christmas Day 1704, at 17h local time (also 17h UT at that time), when it was getting dark, a meteorite fell in Catalonia, causing a fireball in the sky that was seen and heard by many people over an area of several hundred kilometers. The fireball was observed from several different places in southern France and Catalonia (Fig. 1), as deduced from more than twenty reports that have been compiled from official and private historical archives, as well as from personal diaries and chronicles.

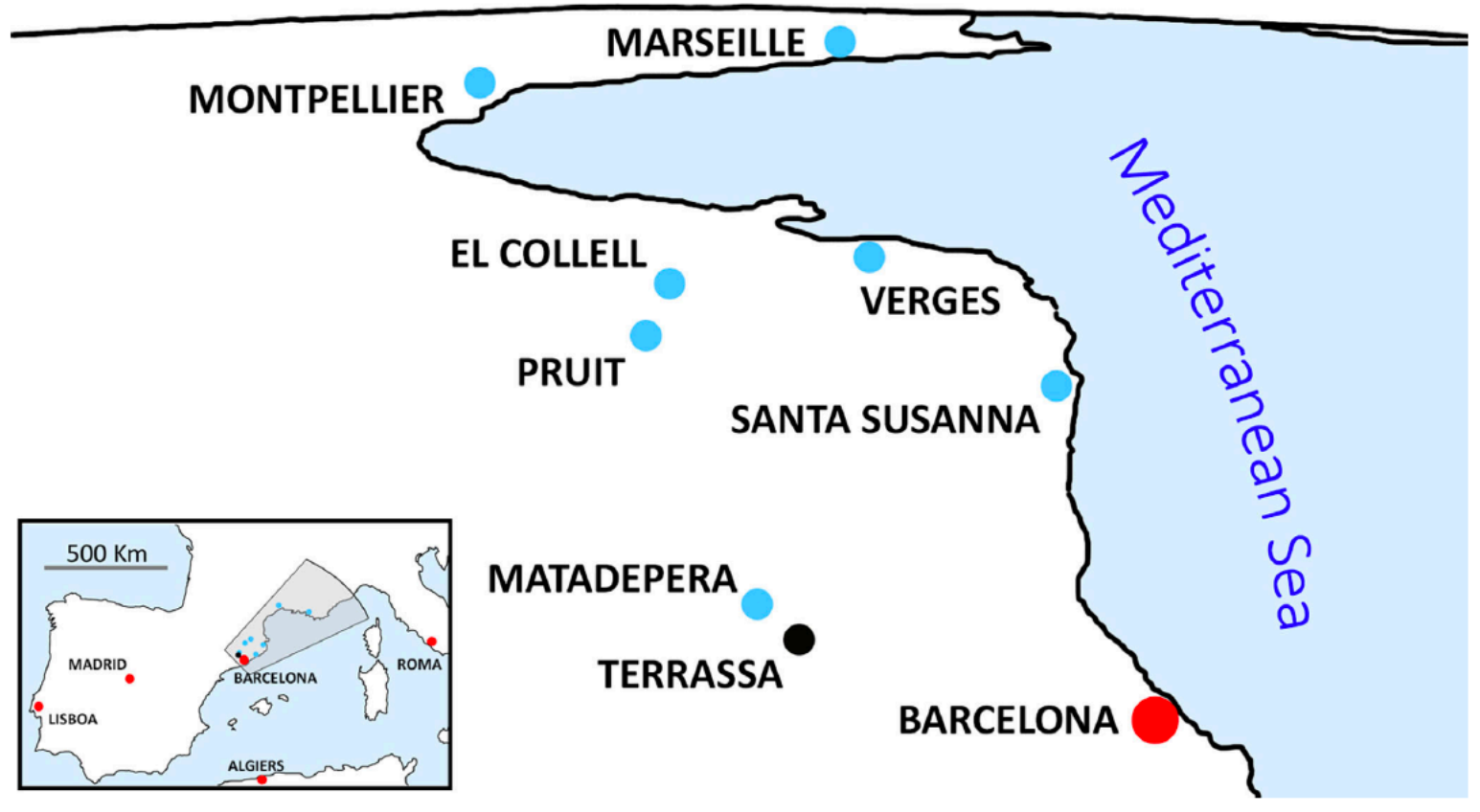

Figure 1. Geographic map with the localities where the fireball was observed and where meteorite fragments were collected (black circle) as stated in the primary source texts.

The first report of the fireball was released shortly after the fall, on December $28^{\text {th }}$. It was a printed communication (in Spanish) published in Zaragoza explaining the great fireball that 
was seen from Barcelona (Anonymous 1704). This communication, entitled "True witness coming from the city of Barcelona to this city of Zaragoza, on December 28, 1704" (Verídica relación venida de la civdad de Barcelona â esta ciudad de Zaragoza, â 28 de Deziembre de 1704), was illustrated with an engraving showing the passage of the fireball over the Earth (tierra) in relation to the Sun, the Moon, and the position of several starry symbols, as observed from Barcelona (Fig. 2a). It should be noted that five of these symbols, along with the Moon and the Sun, were drawn in a circle representing the ecliptic, whereas one was not. After consulting the Stellarium software, it is very interesting to note that the engraving reflects the position of the planets that were visible at the end of December 1704, as well as a brilliant star, Formalhaut (Alpha Piscis Austrini, or $\alpha$ PsA), which was the only bright star south of the ecliptic. Therefore, we have identified (Fig. 2b) the five planets known at that time (Mercury, Venus, Mars, Jupiter and Saturn) and $\alpha$ PsA on the engraving. Also, the sizes of Venus and Jupiter were drawn slightly larger than those of the other planets, according to their brightness. The coincidence of the positions suggests that the engraving was made with the intention of representing the trajectory of the fireball.

a

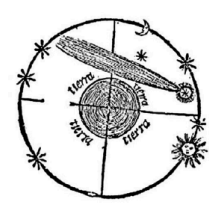

VERIDICA RELACION, VENIDA DE: LA CIVDAD de BARCELONA â crta Ciu. dad d.ZARAGOZA, â 28 .de Deziembre de 1704 .

b

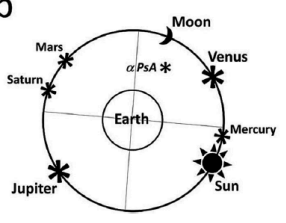

Figure 2. (a) Cover of the printed report that was published in Zaragoza concerning the meteorite fall as seen from Barcelona (Arxiu Històric de la Ciutat de Barcelona). (b) Schematic of the engraving with the identification of the planets and Formalhaut ( $\alpha$ PsA).

In April 1705, a very short item of news was published in French in the Journal de Trévoux, often called the Mémoires de Trévoux, which was an influential academic journal founded by the Jesuits in 1701 . It probably served to publicize the meteorite fall among scholars (Anonymous, 1705b): "It is written from Barcelona that there appeared a new meteor. Those who observed it have promised me details of their observations, which I will communicate to you" (On écrit de Barcelone qu'il y a paru un nouveau Météore. Ceux qui l'ont observé me 
promettant un détail de leurs observations, que j'auray soin de vous communiquer). However, the full report of the meteorite fall was published in Spanish by the lawyer and historian Narcís Feliu de la Penya (1646-1712) in The Annals of Catalonia (Anales de Cataluña) (Feliu de la Peña 1709), a compilation of events that occurred in Catalonia from 1458 to 1709 :

Concluyóse este año 1704 con el horrendo metheoro y señal extraordinario del cielo que apareció día de Navidad a las 5 horas de la tarde sobre Barcelona, descubriéndose de toda Cataluña. Era como una bomba, y a lo exterior opaca, pero salía de ella tal resplandor que superó con manifiesta demostración a la luz del sol. Empezó a inflamarse entre oriente y medio día, corrió luego lucida a occidente, y acabó entre el septentrión y occidente, demostrándose más inflamada y lucida, como un globo de fuego que caía sobre la tierra, dexando una larga señal de humo como una nubecilla que se fue exalando poco a poco, oyéndose después un trueno muy irregular, cuyo estruendo duró un grande rato como disparo de artillería y mosquetería.
The year 1704 ended with the horrific meteor and extraordinary sign from the sky, which appeared on Christmas Day, at 5 o'clock in the afternoon, over Barcelona, and which was observed throughout Catalonia. It was like a bomb, and externally opaque, but the great glow which emerged from it, was brighter than the light of the sun. It began to swell between the East and midday, then veered to the West, and ended up situated between North and West. It was more inflamed and bright, like a balloon of fire falling on the Earth, leaving a long streak of smoke like a little cloud that was slowly disappearing. And then a very irregular thunder blast was heard, whose roar lasted for a long time, like artillery and musketry.

The description of the fireball by Narcís Feliu de la Penya is very similar to other reports such as those, for example, which appeared in Catalan in the diary of the lawyer and politician Manuel Mas y Soldevila (?-1748) (Mas y Soldevila 1705). It was also probably the basis for the report published in the Historical Narrations (Narraciones Históricas) of the War of the Spanish Succession written in Spanish by the aristocrat Francesc de Castellví (1682-1757) (Castellví 1997):

Esta centuria fatal a la Corona de Aragón la predecía con extraordinarios señales el Cielo. En 25 de diciembre a las 5 de la tarde se advirtió en toda Cataluña, y con particularidad más vivo sobre el hemisferio de Barcelona, un espantoso y horrendo meteoro. Era el tiempo sereno y la diafanidad del día añadió horror. Compareció de repente y descubrióse distintamente. Era la forma de un globo de fuego; el exterior, opaco; el centro, color de 
sangre. Salía de él tal esplendor que excedió con manifiesta ventaja la luz del sol, a modo de coruscación. Ceñíale una nube poco clara, y a ésta, otro giro tenebroso y denso que infundía espanto. Así permaneció adverso al sol un grande rato. Empezó lentamente a inflamarse entre oriente y mediodía; se extendió, lúcido, a occidente. Corrió toda la región entre septentrión y mediodía, como cubriéndola y allí acabó, manifestándose más inflamado y lúcido, como que caía sobre la tierra, dejando una larga señal de humo, a modo de nubecilla en forma de columna, que fue exaltándose poco a poco. Oyóse después un irregular trueno, cuyo estruendo duró un grande rato, como un continuo disparo de artillería y fusileria. Los estruendos eran formidables, alternados con intermisiones. Se advirtió por una hora no aquietarse del todo la región. Desvanecido el fuego, que servía de principal objeto a Barcelona, se extendió por toda la Cataluña. /.../

This fatal century for the Crown of Aragon was predicted by extraordinary signs in the sky. On December 25, at 5 o'clock in the afternoon, a terrible, horrendous meteor was observed throughout Catalonia, particularly in the hemisphere of Barcelona. The weather was calm and the diaphanous day made it seem even more horrendous. It appeared suddenly and distinctly. It was the shape of a ball of fire; the outside, opaque; the centre, the colour of blood. It was so much brighter than the sunlight, because of coruscation. Around it there was a fuzzy cloud and a terrific dark and dense twist. It thus managed to remain adverse to the sun for a long time. It slowly began to swell between East and midday; it spread, lucid, to the West. It travelled the whole region between North and midday as if it were covering it, and there it stopped, even brighter, as it fell to Earth, leaving a long smoke signal, like a little cloud in the form of a column, which was slowly extinguished. Then an irregular thunder clap was heard, the roar of which lasted a long time, like a continuous firing of artillery and musketry. The rumblings were formidable, alternating with intermissions. The region did not become quiet again for an hour. Once the fire, which had been located mainly over Barcelona, had disappeared, it spread all over Catalonia. /.../

Additional details of the fireball are encountered in the Ceremonial of the Magnificient Counselors and Regiment of the City of Barcelona (Ceremonial dels Magnifichs Consellers y Regiment de la Ciutat de Barcelona), or Rubrics of Bruniquer, where the fireball was described as seen from Barcelona (in Catalan) (Bruniquer 1916):

Dijous á XXV de desembre de 1704, en Dietari apar, que a les sinch de la tarda, estant seré $y$ sens veurer-se ningún núvol, de repente, se veu una flamarada molt ardent en la present Ciutat, aixint $y$ venint segons verídicas personas del mar, uns dient venia â modo de barra de viga de foch, ê altres ab globo y cua, se ubrí y dexà tres núvols molt blanchs los quals duraren en la regió celeste més de mitja hora, y després de esta flamarada se sentí en lo cel com si se disparaven alguns artillerías y després molta mosquetería que durà cerca de alguns tres credos. Déu nos vulla mirar ab ulls de misericòrdia y donar-nos sa gràcia, amén. 
Thursday, 25th December of 1704, at five o'clock in the afternoon, the sky was serene and cloudless. Suddenly there was a very bright flash, according to reliable testimonies, from the sea. Some people said it was shaped like a bar or like a beam of fire and others claimed that it was like a balloon with a tail. It opened and formed three very white clouds that remained in the celestial region for more than half an hour. After this blaze, sounds like artillery fire and later a lot of musket fire were heard for approximately the time it takes to say three Creeds. May God look on us with mercy and grant us his grace. Amen.

The breakage of the fireball described in the Rubrics of Bruniquer is also reported in the Scientific Miscellany (Miscelánea científica) of Josep Bolló. He was a young grocer settled in Barcelona (Bolló 1717), who produced a colorful drawing entitled (in Latin) Signum magnum aparuit in celo (A great sign appeared in the sky) showing the division of the fireball into three fragments (Fig. 3). The drawing is accompanied by the following text in Catalan (it should be noted that the date of Christmas Day 1705 refers to the old calendar in Western Europe, according to which the beginning of the year was December 25):

Señal del cel que ab grandíssim estruendo aparegué als 25 de desembre, dia de Nadal de I'añy 1705 a las 5 horas de la tarda. Fou cosa molt orrorosa, així per trobar-se lo emisferi ben clar y ceré com per lo gran rimbombo y resplandor que féu.
Sign in the sky which appeared with a really loud noise on 25th December, Christmas Day of the year 1704 [1705 according to the old calendar] at five o'clock in the afternoon. It was a very horrible thing because the hemisphere was clear and calm and it fell with a great roar and blaze. 


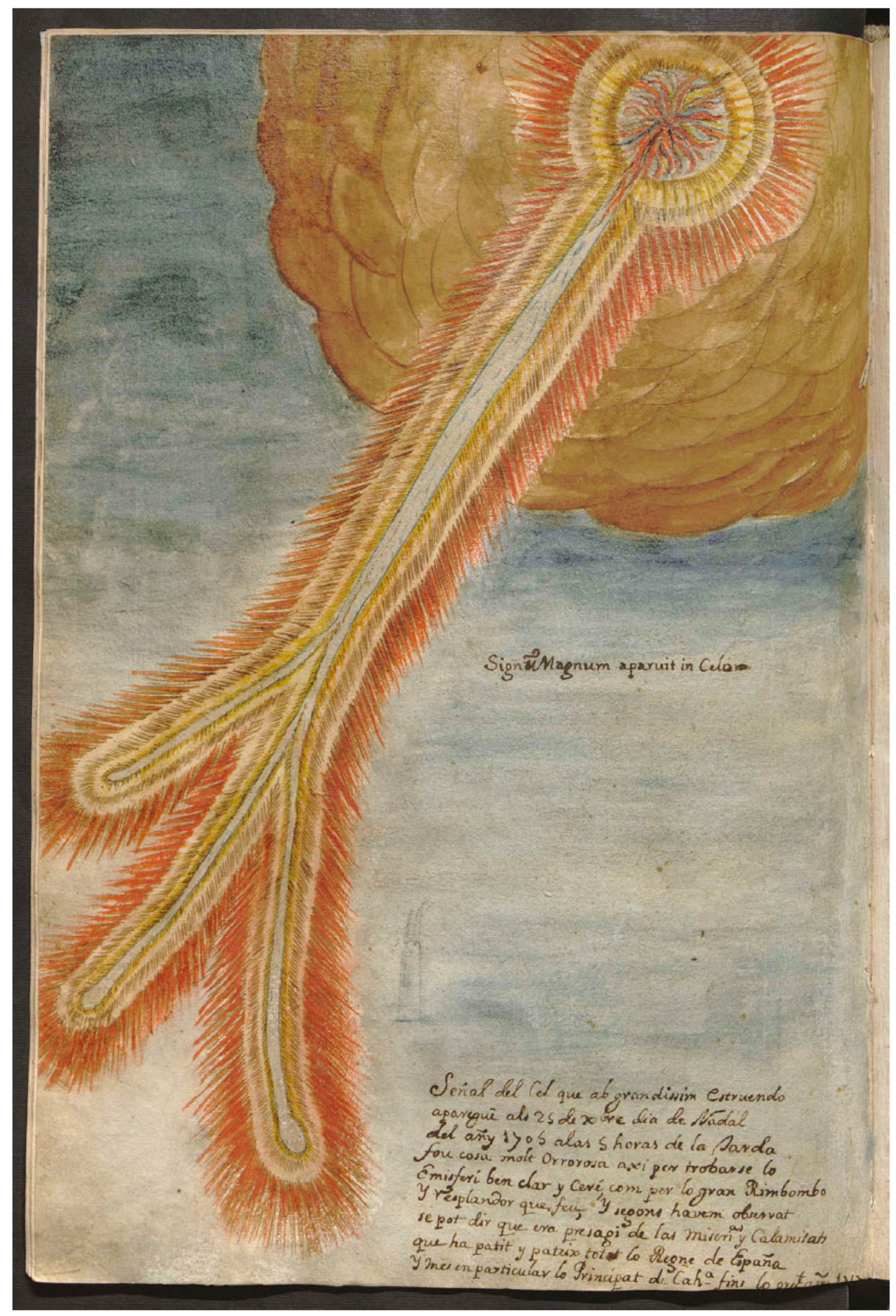

Figure 3. Illustration from the Scientific Miscellany of Josep Bollo (1717) showing the meteorite fall seen from Barcelona (Biblioteca de la Universitat de Barcelona, Ms 95). 
Ernst Florens Friedrich Chladni (1776-1827), the founder of meteoritics (Marvin 2007), included the meteorite fall of Barcelona in his work "New contributions to the knowledge of fireballs and the fallen masses" (Neue Beiträge zur Kenntniss der Feuermeteore und der herabgefallenen Massen), published in German in the Annals of Physics (Chladni 1826). He essentially quoted the data reported by Narcís Feliu de la Penya outlined above:

1704, am Weihnachtstage, also den 25 December, um $5 \mathrm{Uhr}$ ereignete sich in der Gegend von Barcelona ein Meteorsteinfall, der in den Anales de Cataluña por Don Narciso Feliu de la Peña y Farell (Barcelona 1709) libr. XXII. cap. 14 gut beschrieben ist. Die Feuerkugel ward in ganz Catalonien gesehen; sie erschien wie eine Bombe, anfangs ausserlich dunkel, ward immer heller, und übertraf endlich an Glanz das Sonnenlicht; sie entzündete sich (vermuthlich von Barcelona aus gesehen) zwischen $O \ddot{~ u n d} S$, bewegte sich nach $W$, und endete zwischen $N$ und $W$, fiel auf die Erde, liess einen breiten Streifen von Rauch nach, wie eine Wolke, die sich nach und nach zerstreute, und machte schreckliches, lange anhaltendes Getöse wie Kanonen - und Musketenfeuer/.../
On December 25th of 1704, Christmas Day, at 5 o'clock in the area of Barcelona, a meteorite fall occurred as described in the Anales de Cataluña by Don Narcís Feliu de la Penya i Farell (Barcelona 1709) libr. XXII. cap. 14. The fireball was seen throughout Catalonia; it appeared like a bomb, at first darker, becoming brighter, and finally, with a glow that surpassed the sunlight; it ignited (presumably seen from Barcelona) between East and South, moved to the West, and fell to the Earth between North and West, with a broad strip of smoke, like a cloud, gradually dispersing. And it made a terrible, long-lasting noise like cannon and musket fire /.../

In this way, the meteorite fall was incorporated later on in compilations by other authors with the name of Barcelona meteorite, (i.e. Arago 1855, Greg 1861, Faura i Sans 1921). Actually, the meteorite fragments did not fall over the city of Barcelona; they really fell about $25 \mathrm{~km} \mathrm{NW}$ in the vicinities of Terrassa (vide infra). In fact, the fireball was also seen from places other than Barcelona. Another testimony (in Latin) is found in an autograph text by the notary Joan Ferrer Bordila, who saw the fireball from Verges, which is a small town located 105 km NE of Barcelona (Llorca et al. 2002; 2004) (Fig. 1):

In nomine Sanctissimæ Trinitatis, Patris et Filii et Spiritus Sancti. Ad futuram rei memoriam, sciant lectores presentem scripturam legentes qualiter die iouis intitulata festiuitate Natalis 
Domini Nostri lesuchristi, vigésima quinta mensis desembris anno a Natiuitate Domini millessimo septingentessimo quinto, inter quintam et sextam horas serotinæ, serenitate eolisque tranquillitate fruentes, vidimus in emisferio nostro et precipue a parte meridie de celo ignis ardentis signum descendentem versus ocassum ad instar fulguris, magno cum splendore, et terrore omnium circunstantium in terra decurrentem. Postque visionem hanc fere medii quarti spatium magnum audiuimus terremotum Gerundam versus vbi ad aparientiam dictum signum descendit pro vt in illo statu tormentum belli iecissent pugnamque magnam tenuissent. Ex quo pronosticum facimus alicuius rei uenturæ. Placeat omnipotentis Domino Nostro Deo vt sit bona. Amen.
In the name of the Holy Trinity: Father, Son and Holy Ghost. For future memory, let those who read this text know that on Thursday, December 25, 1704, the feast of the Nativity of Our Lord Jesus Christ, between five and six o'clock in the evening, the sky being serene and the wind calm we witnessed a ball of glowing fire, something like a very bright sun beam, coming down from midday and westward direction. All of us being very frightened, we saw how it rushed towards the ground. Then, not even half a quarter of an hour having passed, we heard a kind of great earthquake coming from Girona, a place where apparently the sign had fallen, as if a war had broken out there or a great battle was being fought. From all this, we infer what our future destiny may be. In God's name. Amen.

In the notes and accounts of the heirs of Quatrecases of Pruit (Llibres de comptes i notes dels hereus Quatrecases de Pruit) (1686-1812), the following description of the fireball appears in Catalan as seen from the Collsacabra mountains (Fig. 1), about $80 \mathrm{~km} \mathrm{~N}$ of Barcelona (Ginebra 2005). In this case, the account reports that the smoke trail split in two parts, not three as found in the other records. This could be due to the position of the observer with respect to the fireball trajectory:

Lo dia de Nadal del any 1704 venint jo, Joan Quatrecases, de Pruit, trobant-me aver ja deixat lo camí real y éser al mitx de la plana és sobra la margenada de la devesa prop de un roura gran que.i.à a la vora de dita margenada y prop lo devallant de dita margenada venint per la dressera, he vist una claredat gran que abrigà lo dit roura y a mi, y pasa ab tanta pressa com fan a vegadas los núvols quant fa gran vent y passan per devant lo sol, y tenia la dita claredat que pasa a mi cosa de algunas dos canas de amplària, y veent la dita claredat mirí envers lo sel y he vist un ratx de foch en lo sel, que a la vista mia exia de lo endret del Putx de Catifell y se'n anà a parar a la part de envès mitx soley de la garssa, so és Déu sap a ont finà, però dich faé lo camí en aquex endret y lo dit ratx de foch era gran y dexava al derrere una cuaraña de foch com lo bras y al derrera de dita cuaraña per tot de aont pasa lo dit foch cadà un gran ratx de fum y com més a la fi del foch anave més gran fum cadava, y després lo dit fum se partís per lo mitx en amunt estigué un rato tot entorxat $y$ poch a poch se anà estenent $y$ pardent, y a cosa de alguna ora fou ja perdut, $y$ després de pasat alguna mitat de mitx quart se sentí, y jo lo he oit, un tro molt llony, a la 
part de aont anà a finar lo dit ratx de foch, $y$ sucseí lo dit ratx de foch y tro esent tot saré, no aparexent-se ningún núvol en tot lo món, y lo dit senyal moltísima altre gent lo an vist sense jo.
On Christmas Day of the year 1704 while myself I, Joan Quatrecases, was coming from Pruit, having already left the main road and finding myself in the middle of the plain above the edge of the meadow near a large oak tree near the pathway and on the border of the descent coming via a shortcut, I saw a great flash of light that surrounded the oak and me. It moved as rapidly as the clouds sometimes do when it is very windy and they pass in front of the Sun. I glimpsed something that was twelve feet wide. Seeing this flash, I looked up sky and I saw a ball of fire in the sky, which came from the mount of Catifell and went to stop God knows where. And the ball of fire was large and left behind pieces of fire like embers and behind them and where all the fire went was a large trail of smoke, and the fire left smoke wherever it went. And then the smoke split in half and the sky stayed all smoky and slow for a while. Then the smoke spread out and diminished and after about an hour it had gone. After about a quarter of an hour I heard a distant clap of thunder, in the place where the fireball had been. And the said trail of fire and thunder existed while the sky was totally clear without any clouds appearing in the whole world, and that sign was seen by many people other than me.

From Matadepera, about $30 \mathrm{~km} \mathrm{NW}$ from Barcelona (Fig. 1), another interesting testimony about the fireball is found in the notes (in Catalan) of the peasant Miquel Batlles i Torres (1676-?) (Galí 1993): 
Lo any 1704 al mes de dezembra, lo die 25 que comptam lo die de Nadal, die de la nativitat de Nostre Senyor al vespra en ves toch de havi Maria, se veyhé un senyal al cel molt escarrifós y espantós, que no.l veyé ninguna presona cristiana que no tingués por y gran susto de Déu Nostre Senyor, y lo senyal jo Miquel Batlles lo vax veura y fou de aquesta menera, que.s veyé de tota la cristiandat, segons dihuen molta gent docta y entessa, lo senyal se ha certa de ser allà de hont hés lo sol a la estiu al mitx del die y de pertot se.l veyé, totom sobra de ell, y també sentí la gran remor. I.s que dit senyal, tot en sarè que no.s veya cap núvol en lo món, y féu clarejà la terra com un llampech, y aleshores alsí lo cap al cel $y$ vatx veura un tros de cel bon y obert ab un forat rodó que y auria passat de corraguda qualsevol casa de Catalunya, y se veya dit forat tot vermell de foch molt ardent, y estigué obert lo espay de un credo, y lo fum que.n va axí estigué més de una hora y mitge antas no deshapagué, y en continent que lo senyal del foch agué deshaparagut, se sentí dal al cel com un tir de artillaria y de aquex un altra y altra y després comensaran a sentir los tirs espessos, que de ninguna menera se posquien comptar, y després se resolgueran dits tirs com una bonió de mal temps y axò durà dit suroy dalt al cel lo espay de un quart de hora, y sempra se sentia sobra lo cap de un homa allà de hont se veyé lo senyal del foch, y totom espantat de veura lo que.s veya y sentir lo que se sentia, tot en sarè dalt del cel. /.../
In the year 1704, month of December, the 25th day, which is Christmas, the day of Our Lord's birth, towards sunset, at approximately the time of the Ave Maria, a threatening and terrifying sign was seen in the sky, and there was not a single Christian who did not feel shock and great fear of our Lord God. I Miquel Batlles, saw this sign and it was also seen by all of Christendom, according to many learned and knowledgeable people. The sign appeared at the very point where the sun is at midday in the summer, and for this reason we could see it right above our heads and also hear the great roar. With the sky so clear and not a single cloud visible the sign illuminated the earth like lightning; then I looked up and saw that in a part of the sky a large circular hole had opened through which any farmhouse in Catalonia would easily have passed. The hole had become red from a very hot fire, it remained open for the time it takes to say a Creed, and the smoke that emerged took more than an hour and a half to disappear. Immediately after the fire had disappeared, something similar to an artillery shot was heard in the sky, and then another and another, until the firings began to be heard more and more often and it was impossible to count them anymore, with them finally resembling those shots that are like the dull murmur that usually comes before storms. The rumble lasted a quarter of an hour and was heard above the heads of people in those places from where the fireball had been, and everyone was scared at what they had seen and heard in that completely clear sky /.../

Regarding the observations reported from France, the fireball was spotted from Montpellier and Marseille, about 285 and 340 km NE from Barcelona, respectively (Fig. 1) by the wellknown astronomers Antoine-François de Laval (1664-1728), François de Plantade (16701741) and Jean de Clapiès (1670-1740), who collaborated with the astronomer Jacques Cassini (1677-1756), son of the famous Giovanni Domenico Cassini (1625-1712). The fact 
that the fireball was observed from places separated by about $400 \mathrm{~km}$ shows that the magnitude of the event was remarkable. The following report appeared in French in the History of the Royal Academy of Sciences in 1705; the date refers to December 26, which is probably the date when the report was sent (Anonymous 1705c):

Le Pere Laval Jesuite qui est à Marseille, \& Mrs. de Plantade \& Clapiés qui sont à Montpellier, envoyerent à M. Cassini, avec diverses Observations Astronomiques, la relation d'un Phenomene lumineux qui avoit été veu le 26. Dec. 1704 à 5h30' du soir à Marseille, \& à 5h1/4 à Montpellier. On ne pouvoit douter par les circonstances des deux relations que ce ne fut le même. A Marseille où il fut mieux observé, le Pere Laval vit une Poutre fort lumineuse, poussée de l'Est à l'Ouest assez lentement. Le vent étoit à l'Est. Elle partit d'auprès de Venus, au moins à en juger par la vûë, \& alla jusqu'à la Mer où elle se plongea, tout au plus à deux lieuës au large. On avoit veu auparavant à Marseille, ou aux environs, deux Poutres semblables, \& ayant le même mouvement. A Montpellier, on vit à l'heure marqée un globe de feu tomber à quelque distance de la Ville. L'air étoit alors for serain, \& fort calme, \& une couleur jaune trèsfoible tegnoit tout le Couchant à la hauteur de plus de 10 degrez.
Father Jesuit Laval, who is in Marseille, and Mr. de Plantade and Mr. de Clapiés, who are in Montpellier, provided information for Mr. Cassini, with various Astronomical Observations, about a luminous phenomenon which had been seen on the $26^{\text {th }}$ of Dec. 1704 at $17 \mathrm{~h} 30 \mathrm{~min}$ in the evening at Marseille, and at $17 \mathrm{~h} 15 \mathrm{~min}$ at Montpellier. The circumstances of the two sources make it clear that they refer to the same event. In Marseille, where it was better observed, Father Laval saw a highly luminous beam, pushing from East to West quite slowly. The wind was in the East. It departed from Venus, at least judging by the view, and went to the sea where it plunged in, at least two leagues out. We had previously seen two similar beams in Marseille, or in the neighborhood, moving in the same way. In Montpellier, at the time indicated, a globe of fire was seen falling at some distance from the city. At that time, the air was calm and serene, and a very faint yellow color tinted the entire coast to a height of more than ten degrees.

From all these historical records, it is clear that the fall of the meteorite was, without a doubt, frightening, considering that all the stories have this point in common. That Christmas Day of 1704 in the afternoon the sky was serene, without clouds, an atmosphere of peace and quiet was in perfect harmony with the transcendence of that day, the most celebrated of the Christian liturgical calendar. Suddenly, a totally unexpected and surprising event broke the calm of the dusk; a great ball of fire with luminosity similar to the Sun crossed the sky, leaving a column of smoke visible for a long time. In addition, a great rumble, similar to firearm, accompanied this luminous phenomenon. Despite the diversity of social origin, the cultural level, and the geographical origin of the witnesses, they all coincided both in the 
description of the phenomenon and in its interpretation, which was strongly influenced by the providential and hyper-religious ideas typical of the Baroque mentality. The witnesses described the fireball as a bad omen, a signal that God sent them to warn them that, as had so often happened throughout history, divine fury would come again. They were convinced because they had never seen a fireball before and because it took place on Christmas Day, a symbolic date.

\subsection{The fall of meteorite fragments}

In addition to the fireball, some of the texts discussed above also contain valuable information about the fall of the meteorite. These texts describe the fall of various fragments of the meteorite, in accordance to the explosion of the fireball reported by the witnesses. They also report several places where the meteorite fragments fell. In this regard, the information given in the manuscript written by Miquel Batlles i Torres clearly indicates that the fragments fell in Terrassa and surroundings (Galí 1993):

/.../ y ab algunas parts digueran que aleshoras ab la bonió caygueran unas pedras negras del cel que passaven tres lliuras y altres dues y mitge. Digueran que en la Torra d'en Maduxé de Sant Julià d'Eltura ne avia cayguda una, y a cassa d'en Falguera de Sant Pera de Terrassa una altra, y ab moltas altras pars tanbé es digué que.n vien caygudas, però aqueixas pedras no las avem vistas y per rahó de Estat ho creyhem, perquè lo dit senyal y suroy és axís, ab moltes prèdicas, $y$ de las pedras may n'an parlat...
/.../ and in some places it was said that then, with a rumbling sound, black stones that weighed three pounds and others that weighed two and a half, fell from the sky. People said that in the Torre d'en Maduxé, in Sant Julià d'Altura, one fell, and in Falguera's house, in Sant Pere de Terrassa, another. People commented that they had also fallen in many other parts, and although we have never seen such stones we believe this, considering that everything agrees and that the signs and noises were really as I have said, even though in many reports the stones were never mentioned.

In addition to the place where the meteorite fragments fell, the text written by Miquel Batlles i Torres contains a physical description of the meteorite fragments (black stones) and data regarding the mass of the meteorite specimens (2.5-3 pounds). Taking into account that Catalan pounds are equivalent to four hundred grams, this translates into meteorite fragments of about one kilogram. The descriptions of Mas y Soldevila and Castellví also 
referred to the fragments that fell in Terrassa and, in addition, described the meteorite specimens as "black stones with an ashy core":

/.../ Últimamente desapareció elevándose el vapor a la suprema región del aire. Quedó un poco nublado el día y terminó el horror de la densa sombra sustituyendo la noche las suyas. Cayeron en Tarrasa, cuatro horas distante de Barcelona, unas piedras algo crecidas de color negro y en el centro, cenicientas.
/.../ It finally disappeared and the vapor ascended high up into the air. The day ended up a bit cloudy and night-time replaced the horror of the dense shadows. Some large, black stones with an ashy core fell in Terrassa, which is located four hours away from Barcelona.

The text from Chladni (1826) in the Annals of Physics also described the meteorite fragments, and tentatively suggested that they could be similar to some known achondrites at that time:

/.../ an einigen Stellen vielen grosse Steine nieder, die auwendigschwarz, inwending grau waren. ( $\mathrm{Da}$ in dem Berichte nichts von metallischen Theilen im Innern gesagt ist, so läst sich mit Wahrscheinlichkeit vermuthen, dass die Steine denen von Stannern, Jonzac, Juvenas, u.f.w. mögen ahnlich gewesen seyn, welch kein Gediegeneisen und kein Nickel enthalten).
/.../ in some places many big stones fell, which were black and gray. (As the report says nothing of metallic parts in the interior, it is probable that the stones resemble those of Stannern, Jonzac, Juvenas, and others, which contain no solid iron and no nickel).

In another document by the Franciscan Nicolás de Jesús Belando (1699-1747) it is reported (in Spanish) (Belando 1740) "Likewise, in the place of Terrassa, a stone with a rotund shape fell, which was iron-colored and weighed about seven to eight pounds" (Assimismo en el Lugar de Terraza cayò una piedra de figura rotunda, de color de hierro, y de peso como de siete à ocho libras). Also, in a valuable scripture, written in Catalan by the priest Miquel Garriga, Guardian of the Sant Francesc Convent of Terrassa, we find (Ventalló 1879) “... big stones weighing 12 pounds fell near Terrassa, in the property of Falguera, with the color of fire, and ten or twelve more fell in other places" (...caigueren cerca de Tarrasa, en la heretat 
de·n Falguera, unas pedras mol grosas de pes 12 lliures, de color com si fosen de foch; y ne caygueren deu o dotse en altres diferents llochs). Thus, according to historic documents, several fragments of the meteorite fell in different places around the town of Terrassa $\left(41^{\circ} 34^{\prime} \mathrm{N}, 2^{\circ} 03^{\prime} \mathrm{E}\right)$. These fragments weighed up to $5 \mathrm{~kg}$ and present a black crust and a gray core. These descriptions fit those of the features of a stony meteorite covered with the corresponding fresh fusion crust.

\section{The meteorite fall and the War of the Spanish Succession}

On November $1^{\text {st }}$ of the year 1700, King Charles II of Spain (1661-1700) died leaving no descendants. After the unexpected death at the age of six of José Fernando de Baviera (1692-1699), great-grandson of Philip IV of Spain (1605-1665), who the King had designated as his heir, two candidates ended up claiming the Spanish crown. On one hand, the Archduke Charles of Austria from the House of Habsburg (1685-1740), who was son of the Holy Roman Emperor Leopold I (1640-1705), and on the other hand, Duke Philip of Anjou (1683-1746) from the French House of Bourbon, who was the grandson of the King of France, "the Sun" Louis XIV (1638-1715). On his deathbed and in very unclear circumstances, Charles II eventually appointed Duke Philip of Anjou as his successor. This fact was considered a threat by neighboring kingdoms, believing that an alliance between France and Spain endangered the balance of forces that existed in Europe at that time. In addition, the trade monopoly with America was also at stake. England, the Netherlands and the Austrian Empire constituted the Great Alliance of Hague in 1701, while Portugal and Savoy would join later, to support the claims of Archduke Charles of Austria. In March 1702 war broke out between the Great Alliance and the kingdoms of France and Spain, where Duke Philip of Anjou was appointed as the new King of Spain with the name of Philip V. This historic conflict is well known as the Spanish Succession war, which is considered the first large-scale war, which took place in modern Europe. The absolutist government of Philip V and his Viceroy Francisco Antonio Fernández de Velasco y Tovar, who imprisoned Narcís Feliu de la Penya, the first person who reported the meteorite fall of Barcelona, for supporting Archduke Charles of Austria, did not please people in Catalonia, who believed that their freedoms and constitutions of Catalonia were increasingly being threatened. Opposition to Philip V grew daily, and in the summer of 1705 , there was an uprising in support of the Archduke Charles 
of Austria, who was proclaimed in Catalonia as King Charles III of Spain. At that time Spain therefore had two kings! Just a few months before these events, on no less a day than Christmas Day 1704, there was the fall of the meteorite of Barcelona.

Immersed in this war environment, most of the historical records coincide in attributing a divine origin to the event: the sign came from heaven and it was on a day as emblematic as Christmas Day. People thought that this was a sign sent by God as a warning of the terrible events that were taking place in Catalonia and throughout Europe in the War of the Spanish Succession. The priest Patllari Ombravella Monell (?-1767) from the Sanctuary of Collell, about 95 km NE of Barcelona (Fig. 1), wrote (in Catalan) (Constans 1950):

/.../ y en axó se formá pretenció donant principi á la forta guerra y treballs, com se veu per la experiencia y practicha; la qual se dona a comprendrer (segons judici y experiencia de homes vells) aquell gran Senyal de foch ques veu lo día de Nadal lo any 1704 á la entrar del fosch cerca del toch de la oració que aparagué com una biga gran de fusta ensesa de foch que baxava del Cel y anava passant sens entretenirse; la qual se colgá y se perde de veurer del costat que es entre Mitgdie mes tirat a ponent; $y$ al perdrer de veurer aquell se hoya un gran estruendo en dita part com si fes un tro molt profundo; e o be la terra tonas o tremolas ab admiració dels hoyents, los quals tots los experimentats y personas vellas deyen que devia designar y asenyalar treballs $o$ guerra, com en realitat se veu y passa en practica.
/.../ and with this the bloody war and the hardships began, as evidenced by experience and practice, which became evident (according to the criteria and experience of our elders) in that great fireball that we saw on Christmas Day 1704 at dusk, approximately at prayer time, when a sort of great beam of burning wood appeared and fell from the sky and crossed it without stopping, ceasing to be visible when it was going in the direction between midday tending more towards the west. And when the signal was lost, there was a great roar in that area, like very intense thunder, as if the earth trembled, causing the admiration of those who heard it, among whom the most experienced and elderly affirmed that the phenomenon indicated hardships or war, as actually can be verified and happens in practice.

A divine interpretation can be read in another document written in Catalan, in this case in the memoirs of Francesc Gelat (1687-1722), a peasant from Santa Susanna, located on the coast about 55 km NE from Barcelona (Fig. 1) (Pons i Guri 1959): 
Tanbé noto que lo dia de Nadal de l'any 1704, axís que lo sol se era post, aparagué un señal com una gran barra de foc, que caigué del cel, que causà gran espant. I caigué a la banda de sol ponent, que nosaltres nos aparexia de casa.nfora, que.l miràvem per sobra casa.n Xirau, i després, al cap de mitx quart del señal, sentíram un estruendo com si tiraven pessas $i$ moscateria, ab què totom judicà que Déu nos enviava aquell señal per los treballs i guerra que està passant. Avui, als 12 de matx de 1706, fas esta nota. Si Déu me dóna vida, aniré continuant lo que soseirà...
I also record that on Christmas Day 1704, as soon as the sun had set, there appeared a sign similar to a great bar of fire, which fell from the sky and caused great fright. And it descended in the direction of the west and we, watching it from our home, saw that it passed over Xirau's house. Then, after a half quarter of an hour, we heard a roar similar to cannon and musket fire, so that everyone thought that God was sending us that sign announcing the hardships and the war that we are suffering. Today, May 12th of 1706, I write this note. If God allows me to live, I will keep writing down what will happen.

In the Historical Narrations of Francesc de Castellví, who fought for the Austriacist side, a similar interpretation is found (Castellví 1997):

Estos presagios dio la naturaleza, instruida de la Providencia; y aunque todos son vulgares fenómenos, amenaza Dios con ellos para correr a la enmienda de los vicios. Esto dio asuntos a varias interpretaciones, según lo vario de los efectos. Difundida la noticia en Europa, muchos lo consideraron presagio de lastimosos sucesos. En España se temió común infortunio; en Cataluña, atemorizó a los más; admiró a todos. A pocos les pareció preludio de felicidades. Los más reflexivos discurrieron vaticinio de sangrienta guerra en los límites de la Corona de Aragón, y en particular en Cataluña, y que la España toda sería sangriento teatro de infelicidades. Todo el vulgo lo tuvo a fatal agüero.
These omens were given by nature, instructed by providence; and although they are all common phenomena, God threatens us with them to amend our sins. This resulted in several interpretations due to the variety of effects. Once the news spread in Europe, many considered it a presage of pitiful events. In Spain, common misfortune was feared; in Catalonia, it frightened the bravest and everyone admired it. Few people considered it to be good news. The most thoughtful people predicted a bloody war within the limits of the Crown of Aragón, and particularly in Catalonia, but also in Spain there would be a bloody theater of unhappiness. Everybody interpreted it as a fatal omen.

The jurist Josep Plantí ( 1680-?), judge of the Court of Sardinia during the war, tried to reinforce the symbolism of the meteorite fall with cabalistic allusions to the coincidence of the number five in the event. From the point of view of numerology, the number five was 
considered magic; it was represented by the five-pointed star, the pentagon, represented the fifth element (the ether), and identified the Phythagorean School through the pentagram, etc. In his manuscript "On the death of Charles II King of Spain. On the defeat of Catalonia and the destruction of Barcelona practically achieved" (De morte Caroli Secundi Hispaniarum Rex. De excidio Cathaloniae nec non destructione Barcinonis quasi secundam), Josep Plantí wrote (Alcoberro 2003):

El dia vint-i-cinc de desembre, començant l'any cinquè del naixement del Senyor, segons el còmput vulgar del segle XVIII; I'any cinquè del pontificat de Climent XI; regnant per la cinquena indicció a Espanya Felip V, i I'any cinquè del seu regnat, a la cinquena setmana, a la cinquena hora de vespre, al punt en què el rellotge començava a marcar aquesta hora; [...] un llamp va brillar al cel serè des de I'orient. El globus es va encendre com el sol o com la lluna plena damunt de Barcelona, cap del Principat de Catalunya, amb el qual una línia i el foc a la visió de tres colzes, feta des de migjorn a septentrió, romangué durant un cert temps, convertida en una línia de núvols, i a poc a poc s'esvaí amb un soroll d'armes $i$ de tempestes bèl-liques. Aquest fet horrible el vaig contemplar jo mateix: una cosa més horrible no l'havia llegida excepte en les grans desgràcies i derrotes i no sabria pas dir què significava.
On the twenty-fifth of December, beginning the fifth year of the birth of the Lord, according to the common computation of the eighteenth century; the fifth year of the pontificate of Clement $\mathrm{XI}$; in the fifth year of the reign in Spain of Philip V, to the fifth week, to the fifth hour of the evening, to the point in which the clock began to chime this hour; [...] a thunderbolt shone in the serene sky from the East. The globe was lit like the Sun or like the full moon over Barcelona, capital of the Principality of Catalonia, with which a line and fire to the vision of three cubits, moved from noon to northerly, remained for a certain time, changed into a line of clouds, and gradually faded with a noise of weapons and war storms. I watched this horrible event. I had never observed a more horrible thing except in great misfortunes and defeats and I cannot say what it means.

From another perspective, the broadsheet "Complaints from Barcelona to the tyranny of the Velasco's government" (Clamors de Barcelona, al tirà govern de Velasco), a document written in Catalan and issued in Barcelona to denounce the repression of Velasco (Viceroy of Philip V) against Catalonia, starts with none other than verses that refer to the meteorite fall (Anonymous 1705a): 
Essent de tantas maneras los Catalans vltrajats:

claman los de Barcelona á quin temps som arribats.

En lo any mil set cents, y sinch en lo dia de Nadal

volgue lo Cel avisarnos ab vn horroros senyal: avis era del molt mal que aquí aviam de passar.
Being Catalans outraged in so many ways, people from Barcelona complain about these days.

In the year one thousand seven hundred and four [1705 according to the old calendar] on Christmas Day,

the sky wanted to warn us with a terrible sign: it was a warning of the bad things we would have to endure.

The Barcelona meteorite fall was also used for propaganda purposes. It is a similar case as the well-known broadsheet written by Sebastian Brant (1457-1521) in 1492, which attributed the fall of the famous Ensisheim meteorite on November $7^{\text {th }}$ of 1492 , to a divine sign in favor of Maximilian I (1459-1519), Holy Roman Emperor, in his war against the King of France, Charles VIII (1470-1498) (Marvin 1992). In the case of the Barcelona meteorite, an exceptional document was written in 1705 by Joan Solar, a physician living in Barcelona, who argued that the meteorite fall (along with other celestial phenomena such as the passage of comets or planetary conjunctions) was a sign of heaven in favor of Archduke Charles of Austria in the War of the Spanish Succession. The propaganda manuscript was written in Spanish and printed in Barcelona and contains a beautiful engraving (Fig. 4), which shows the fall of the stones from the sky, entitled "Christmas Day sign" (Señal del día de Navidad) (Solar 1705):

Pues que dirè de aquel prodigiosos señal Celeste, que sucediò el dia 25. De Deziembre de 1704. Dia de la Navidad de JESV-CHRISTO Nuestro Señor, que pareciò mas milagroso, que natural /.../ De la misma suerte sucederán los augmentos y progresos de la Casa de Austria, y en particular favorecerán dichos Influxos á nuestro Rey, y Monarca CARLOS tercero.
What can I say about that prodigious celestial sign, which happened on December $25^{\text {th }}$ of 1704 , Christmas Day of Jesus Christ Our Lord, which seemed more miraculous, than natural /.../ The success and progress of the Austrian Empire will suffer the same fate, and in particular such influences will favor our King and Monarch Charles III. 
SEñAL DEL DIA DE NAVIDAD.

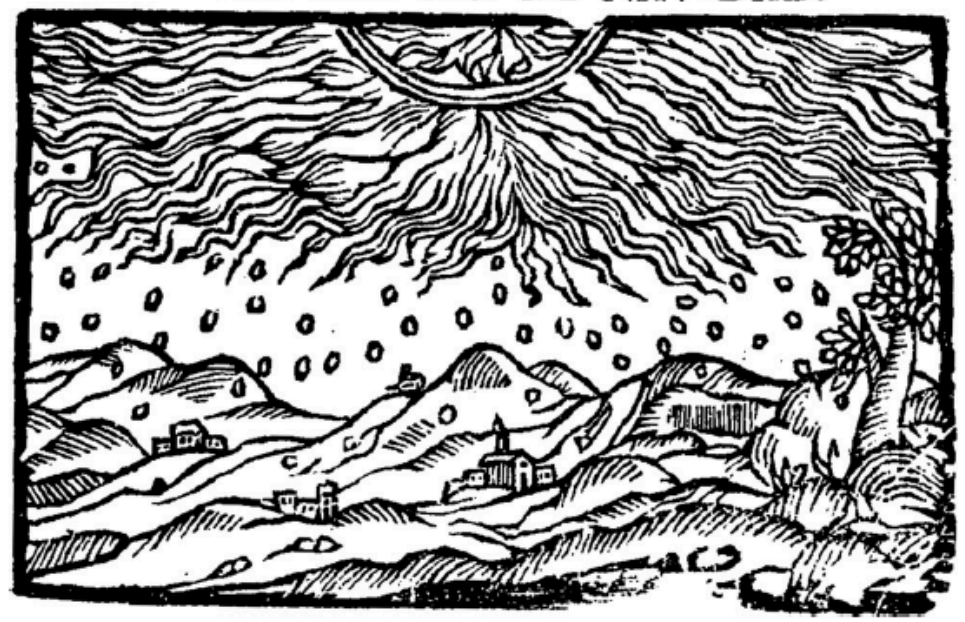

Figure 4. Engraving that illustrated the writing of Joan Solar about the Barcelona meteorite fall. A set of stones fall under a burning sky. (Biblioteca de Catalunya - Solar 1705).

In a similar way, in another broadsheet written in Spanish and printed in Barcelona in 1706 entitled "Naked truth armed with reason" (Verdad desnvda armada de razón), the meteorite fall was also used to support Archduke Charles of Austria against Philip V (Anonymous 1706):

Aun mayores señales han de convencerte: acuerdate del horroroso, que sobre la Ciudad de Barcelona se viò, y oyò dia de Navidad (que fue à todo el Orbe notorio) primer dia, según el computo Eclesiastico del año 1705. dia 5. de la Semana, hora 5. de la tarde, que causò a todos assombro; Por el qual vn grande Astrologo (como lo han comprobado los sucessos de otros juizios) pronosticò ser señal, que avia de acabar el gobierno de Felipe $V$.
Even more signs must convince you: remember that horrible thing that was seen and heard in the City of Barcelona on Christmas Day (which became notorious throughout the whole world) on the first day of the year 1705, according to the Ecclesiastic computation [December $25^{\text {th }}$ of 1704], on the fifth of the week, at 5 o'clock in the afternoon, and which surprised everyone. A great Astrologer (as has been verified in other occasions) predicted that it was a sign indicating the end of the reign of Philip V.

However, shortly afterwards, the propaganda carried out by the court of King Philip V, issued a document in Catalan entitled "Catholic exhortation to the Catalan nation" (Exortació Catholica dirigida a la Nació Catalana), where the Barcelona meteorite fall was used as evidence of a divine warning. The document was addressed to the 
Catalans to convince them of the usurpation committed by Archduke Charles (Anonymous 1707):

La vinguda de nostre Rey Phelip Quint y sa Coronaciò fou pacifica y aprobada per lo Summo Prelàt que tenim en la Santa Iglesia, lo qual encare lo aprobà; luego aquest es lo Rey, que havèm de creurer, vingùt de la ma de Deu; y que tota esta conquista del Senyor Archiduch turbulenta, y plena de abominacions, es una permissiò Divina, en que han deixàt correr las cosas ab las incitacions dels esperits diabolichs per castich de nostras culpas, y pecats: com ne tinguerem manifest avis, $y$ patent amanasa $a b$ aquell senyal de foch, $y$ estruendo extraordinari, que verem $y$ ohirem sobre nostra Ciutat de Barcelona, y se difundi per tota Catalunya en lo Solemne dia de festivitàt de Nadal del any 1704 à las sinch horas de la tarda, en lo qual temps (segons la experiencia nos ha ensenyàt), se anava mes fortament fraguant la rebeldia, $y$ trahiciò en aquells que intentavan introduir al Senyor Archiduch en Catalunya.
The arrival of our King Philip $V$ and his coronation was peaceful and approved by the high priest of the Holy Church; therefore he is the King, whom we have to believe, appointed by the hand of God. All the turbulent conquests of Lord Archduke which are full of abominations and are permitted by God, have happened with the incitement of devilish spirits to punish our guilt and sins. We received a clear warning and threat with the sign of fire and extraordinary noise that we saw and heard over our city of Barcelona and which spread throughout Catalonia on the solemn Christmas Day of the year 1704 at five in the afternoon, at the same time (according to our experience) that the rebellion and betrayal of those who were trying to introduce Lord Archduke to Catalonia were being strengthened.

In the beginning, the War of the Spanish Succession was favorable to Archduke Charles of Austria, but an unexpected incident changed the course of events. In April 1711, the Emperor of Austria, Joseph I, died, and his brother, who was none other than Archduke Charles, inherited the crown of Austria. The kingdoms of the Great Alliance thought that the possible alliance between Spain and Austria was even more threatening than the alliance between Spain and France, and they decided to negotiate peace with the King of France Louis XIV and recognize his grandson Philip V as the King of Spain through the treaties of Utrecht (April 1713) and Rastatt (March 1714). Catalonia, which supported Archduke Charles of Austria, was abandoned to its fate in spite of the Treaty of Genoa signed in 1705 , which established a political and military alliance between the Kingdom of England and Catalonia. On September 11 1714, the Bourbon troops 
invaded Barcelona and Catalonia lost all its political institutions through the promulgation of the Decree of Nueva Planta (1716). In the Scientific Miscellany (Miscel/lània científica) of Josep Bolló (1717), written in Barcelona after the war, the meteorite fall was identified, without a doubt, as an omen of the war and the subsequent fierce repression of the Catalans by Philip V (Fig. 3):

...y segons havem observat se pot dir que era presagi de las misèrias y calamitats que ha patit y pateix tot lo regne de España y més en particular lo principat de Cathalunya fins lo present añy de 1717. ...as we have observed, it can be said that it was a presage of the miseries and calamities that we have suffered and we will continue to suffer in the Kingdom of Spain and, in particular, in Catalonia until the present year 1717 .

Also in the "Prophetic key" (Llabe profetica), an epic text written in Spanish after the war by the court of King Philip $V$ to punish the supporters of Archduke Charles of Austria, the meteorite fall was again ascribed to a divine action in favour of Philip $\mathrm{V}$ (Anonymous 1713?):

Bien se viò en Cataluña la vispera de la Natividad del Señor, año de 1704. donde se admirò vn globo de luz, que venciédo la negra obscuridad de las sombras, iluminò los edificios de la Ciudad de Barcelona. Bien se oyò la voz del Señor, que sobre las aguas del Mediterraneo, en estruendosos ecos horrorizò los animos. Bien se podían prevenir por las señales que el Cielo manifestò essa noche las desgracias que amenazavan al Principado. /.../ Bien dezia aquel Globo de fuego, que el enemigo se acercava à sus puertas, bien mostrava la ceniza q el Cielo lloviò en algunos Pueblos, que las avrian al enemigo para su estrago. /.../ Fue, pues, aquel Globo de fuego para
Cataluña indicio cierto de lo que ha experimentado: fue pronostico de q queria cumplirles Dios sus deseos para castigo suyo.

A globe of light was seen in Catalonia on the eve of Christmas Day in 1704, which, overcoming the black darkness of the shadows, illuminated the buildings of the City of Barcelona. The voice of the Lord was heard over the waters of the Mediterranean, whose thunderous echoes horrified our souls. The misfortunes that threatened Catalonia could have been prevented perfectly by the signs that Heaven manifested that night. /.../ That 
globe of fire clearly showed that the enemy was approaching our doors, showing the ash that rained from the sky in some villages, which opened them to the enemy for their destruction. /.../ That balloon of fire was, therefore, a true indication of what Catalonia has experienced. It was a prognosis that God wanted to fulfill His wishes for their punishment.

From all these historical documents it can be definitively concluded that the fall of the meteorite caused great alarm among the local population. It has also been proved that the fall was used as propaganda by both sides involved in the War of the Spanish Succession in order to encourage or scare people (depending on the side involved) at a time of scientific darkness dominated by the fear of God. This took place almost one century before the well-known book Ironmasses by Chladni appeared in 1794, giving a convincing scientific explanation for meteorite falls (Marvin 2007), and well before the first chemical meteorite analysis (Sears and Sears 1977). Thanks to the quantity and quality of the written documents found so far, the fall of the Barcelona meteorite provides an invaluable opportunity to study the interpretation of meteorite falls in a prescientific time.

\section{Recovery of fragments in the Salvador Cabinet}

We found the meteorite fragments of the Salvador collection in a glass jar referenced as number 205 (Fig. 5) along with a small envelope with the annotation written in Catalan " $n^{\circ} 205$ Meteorite?" ( $n^{\circ} 205$ Meteorit?). Inside the envelope we discovered an old label glued to a piece of paper. The label, written in Catalan, is incomplete and the ink has lost density, but it is still possible to read: "Stone that fell from [...] in [...]1704" (Pe[d]ra [que ca]ygué d'un [...]u es[...] en [...]y 1704) (Fig. 6). The whole set is currently catalogued in the Salvador collection: reference Salv-8355.

Nothing is known about how the fragments of the meteorite reached the collections of the Salvador family. Jaume Salvador i Pedrol (1649-1740), the patriarch, was already in possession of a considerable number of specimens of animals, plants, minerals, fossils and other curiosities, but it seems that the organization of those collections as a museum or Cabinet did not begin until 1707, after his son Joan Salvador i Riera (1683- 
1726) returned from his Great Tour along France and Italy to study botany and chemistry with the best scholars of that time (Camarasa 2018). In 1710, Joan Salvador accompanied the protophysician of Catalonia on a visit to apothecaries from different cities in Catalonia, Terrassa among others (Jordi 1982). There they visited at least three apothecaries. Therefore, we can hypothesize that someone from the Terrassa apothecaries could have been in possession of some fragments of the Barcelona meteorite and gave them to Joan Salvador.

The small envelope and its annotation could be dated near 1938, when the Salvador Cabinet was acquired by Botanic Institute of Barcelona. Pius Font i Quer (1888-1964), the founder of this institution, rescued this collection abandoned for more than a century in a farmhouse thanks to a decree of the Generalitat de Catalunya (Ibáñez 2006). Probably, the glue used to fix the piece of paper also dated from this time. The label, that could date from the 18th century, is originally from the Salvador family, but it does not seem to have been handwritten by Jaume Salvador i Pedrol or Joan Salvador i Riera (the most important members in the family); perhaps an amanuensis transcribed the original data. The jar is made of mouth-blown glass, the traditional method used in the 18th century.

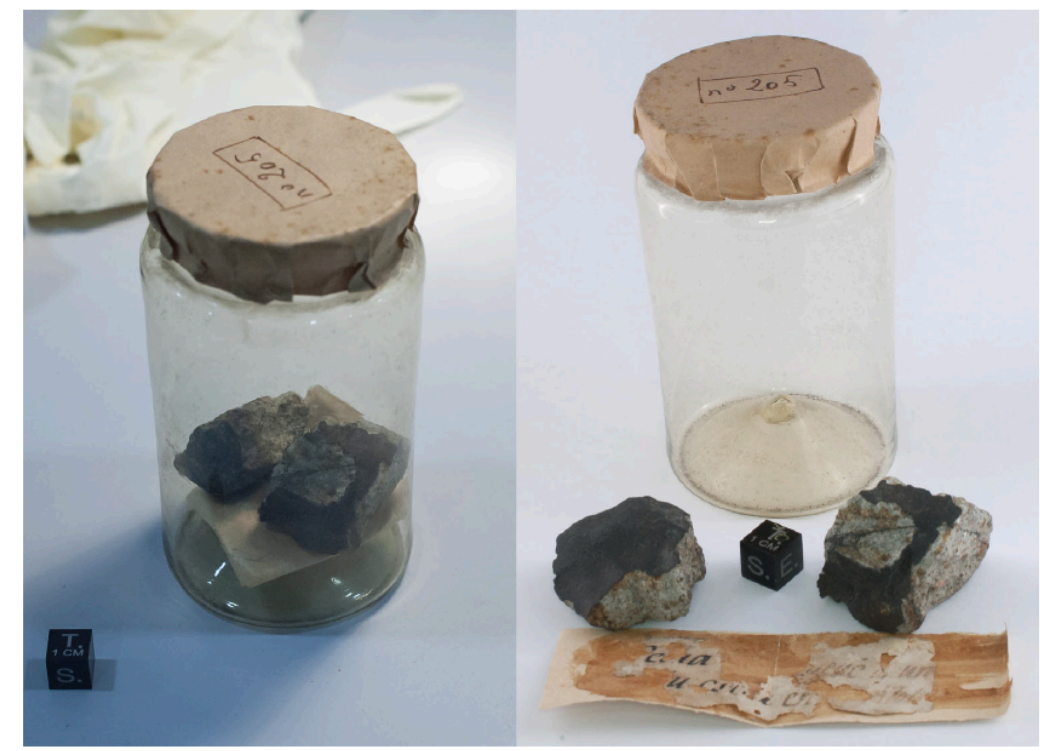

Figure 5. Fragments of the Barcelona meteorite with their corresponding associated label, in the original glass jar in which they were found in the Salvador Cabinet collection (Salv-8355). 

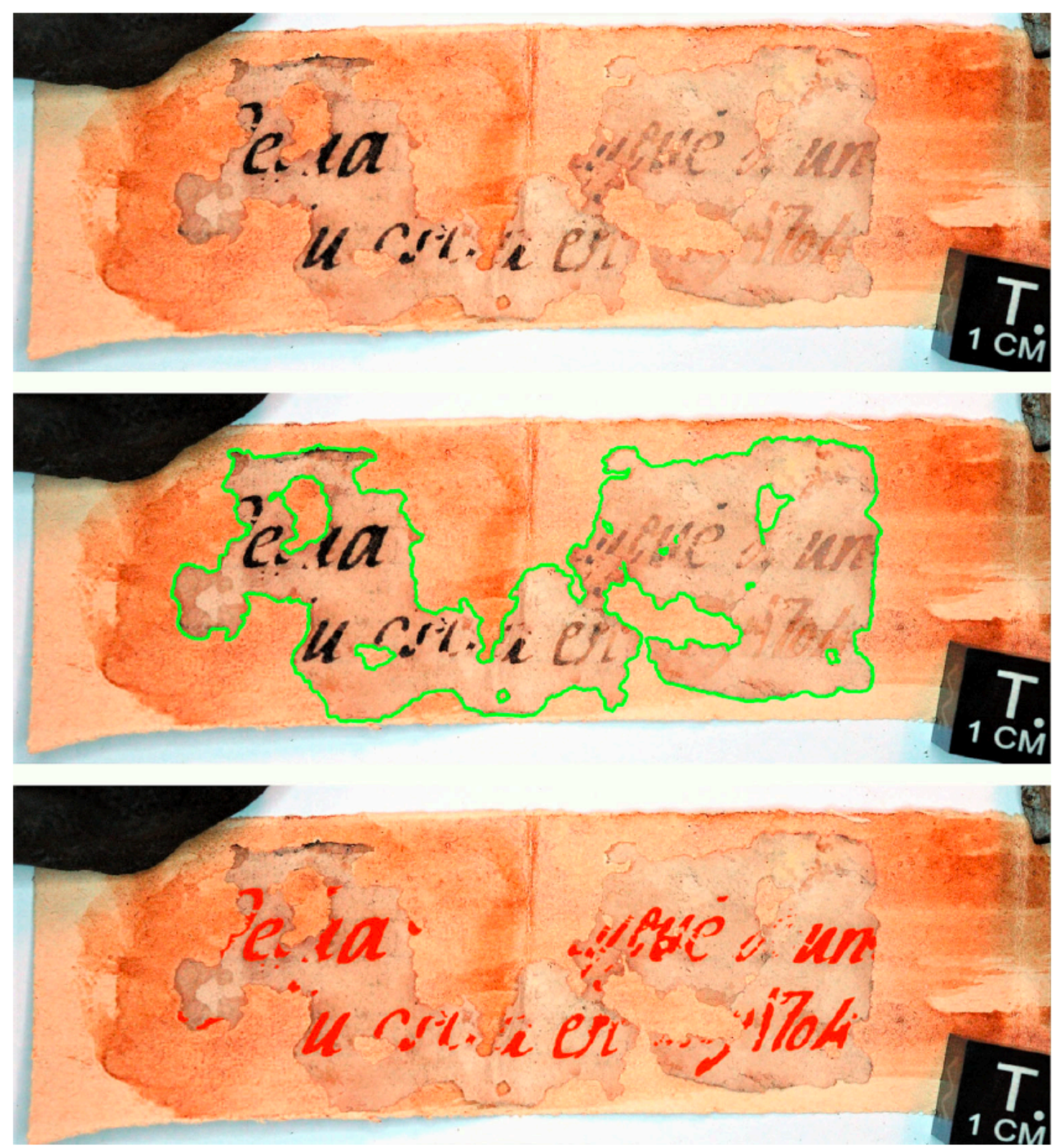

Figure 6. Analysis of the label found in the glass jar where the meteorite fragments were preserved for more than three centuries. The green line delimits the border of the old label and the red type corresponds to the digital reconstruction of the text. 


\section{Analysis of the meteorite}

\subsection{Methodology}

A polished thin section of the meteorite $\left(\sim 2.4 \mathrm{~cm}^{2}\right)$ was obtained from the $49.8 \mathrm{~g}$ fragment in the Laboratory of Paleontological and Geological Preparation (LPGiP) from the MCNB in order to carry out petrographic and geochemical studies and its corresponding classification. Previously, 3D digital models and replicas of the fragments were carried out by the Conservation and Restoration Department of the MCNB. The meteorite thin section was studied by petrographic microscopy and by scanning electron microscopy (SEM), using a FEI Quanta 200 instrument operating at 15-20 kV accelerating voltage and $5 \mathrm{nA}$ beam current and equipped with an energy-dispersive spectrometer at the Scientific and Technological Centres of the University of Barcelona (CCiTUB) and at the Barcelona Research Center in Multiscale Science and Engineering at the Technical University of Catalonia (UPC). Electron probe microanalysis (EPMA) was performed on a JEOL JXA-8230 electron microprobe equipped with 5 wavelengthdispersive spectrometers (WDS) at the CCiTUB. Spot analyses were carried with an accelerating voltage of $20 \mathrm{kV}$, a beam current of $15 \mathrm{nA}$, and a spot size of 1-2 microns. Analytical standards used were: hematite $(\mathrm{Fe}, \mathrm{LIF}, \mathrm{K} \alpha)$, rutile $(\mathrm{Ti}, \mathrm{PET}, \mathrm{K} \alpha)$, periclase $(\mathrm{Mg}$,

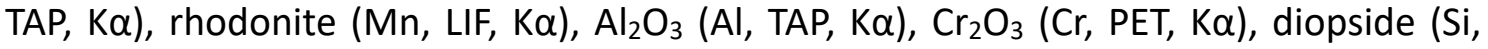
TAP, K $\alpha)$, sphalerite $(\mathrm{Zn}, \mathrm{LIF}, \mathrm{K} \alpha)$, NiO $(\mathrm{Ni}, \mathrm{LIF}, \mathrm{K} \alpha)$, wollastonite $(\mathrm{Ca}, \mathrm{PET}, \mathrm{K} \alpha)$, metallic

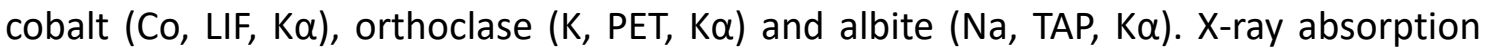
computed microtomography was performed at UPC on a Bruker Skyscan 1272 instrument at $70 \mathrm{kV}, 114 \mu \mathrm{A}$, integration time of $600 \mathrm{~ms}$ and voxel size of $30 \mu \mathrm{m}$.

\subsection{Description and petrography}

The fragments of the Barcelona meteorite preserved in the Salvador Cabinet collection weigh 49.8 and $33.7 \mathrm{~g}$, respectively, and they are partially covered by a dark, smooth, and shiny fusion crust, which is a clear indication that they were recovered shortly after the fall (Fig. 7). Shock melt veins are abundant. 


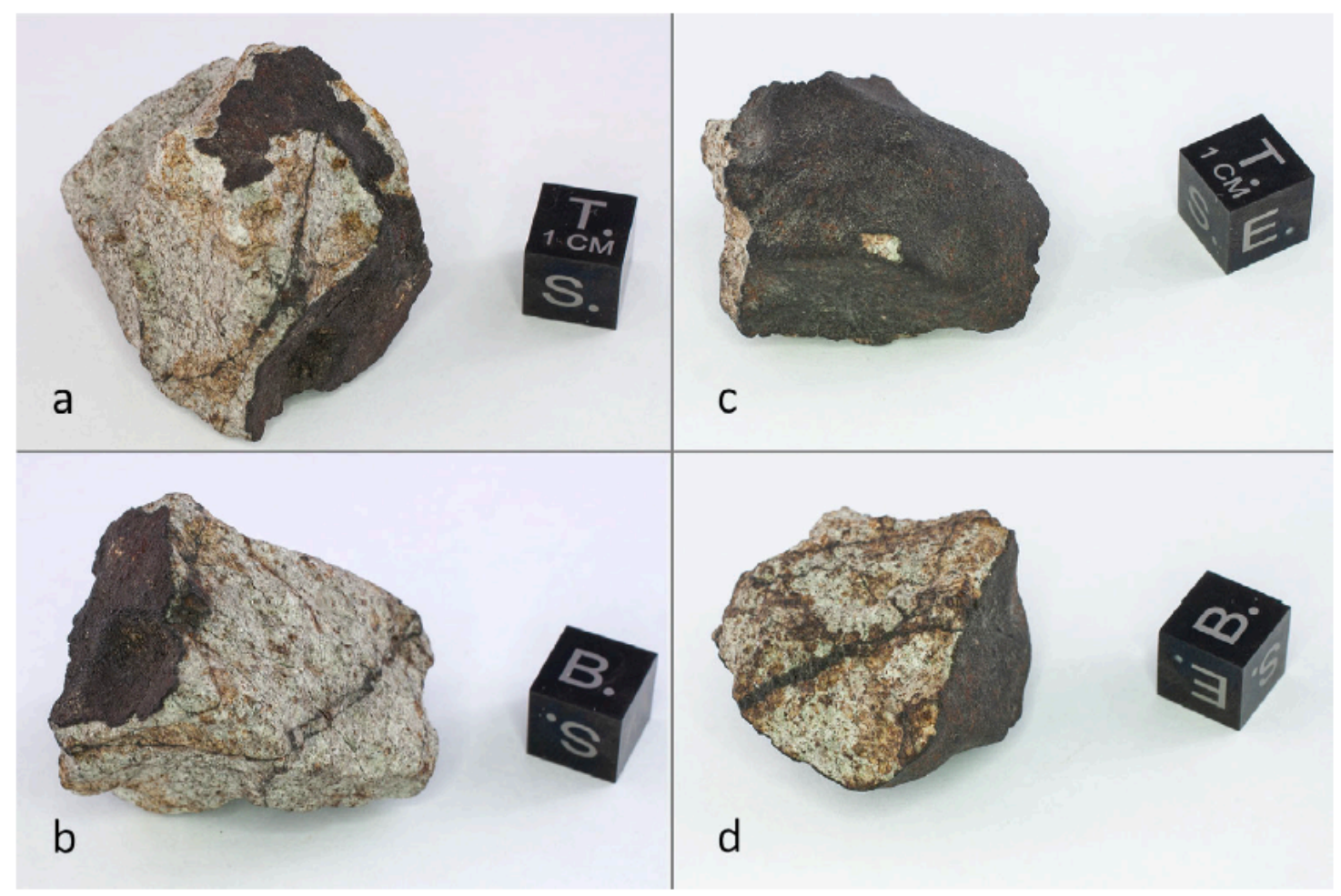

Figure 7. Detailed pictures of the Barcelona meteorite fragments (left, fragment of $49.8 \mathrm{~g}$; right, fragment of $33.7 \mathrm{~g})$.

Figure 8 shows a general view of the thin section in transmitted, reflected, and crosspolarized light as well as in SEM backscattered electrons (BSE). Several chondrules with an apparent diameter ranging from ca. 0.8 to $5 \mathrm{~mm}$ and shock melt veins are easily recognized. The chondrules exhibit porphyritic olivine pyroxene (POP), barred olivine (BO), granular olivine pyroxene (GOP) and radial pyroxene (RP) textures. Figure 9 shows representative SEM (BSE) images of shock melt veins, chondrules and matrix. Xray absorption computed microtomography performed in a volume of $0.83 \mathrm{~cm}^{3}$ reveals that the meteorite contains about 3.1 vol\% metallic Fe-Ni uniformly distributed. 


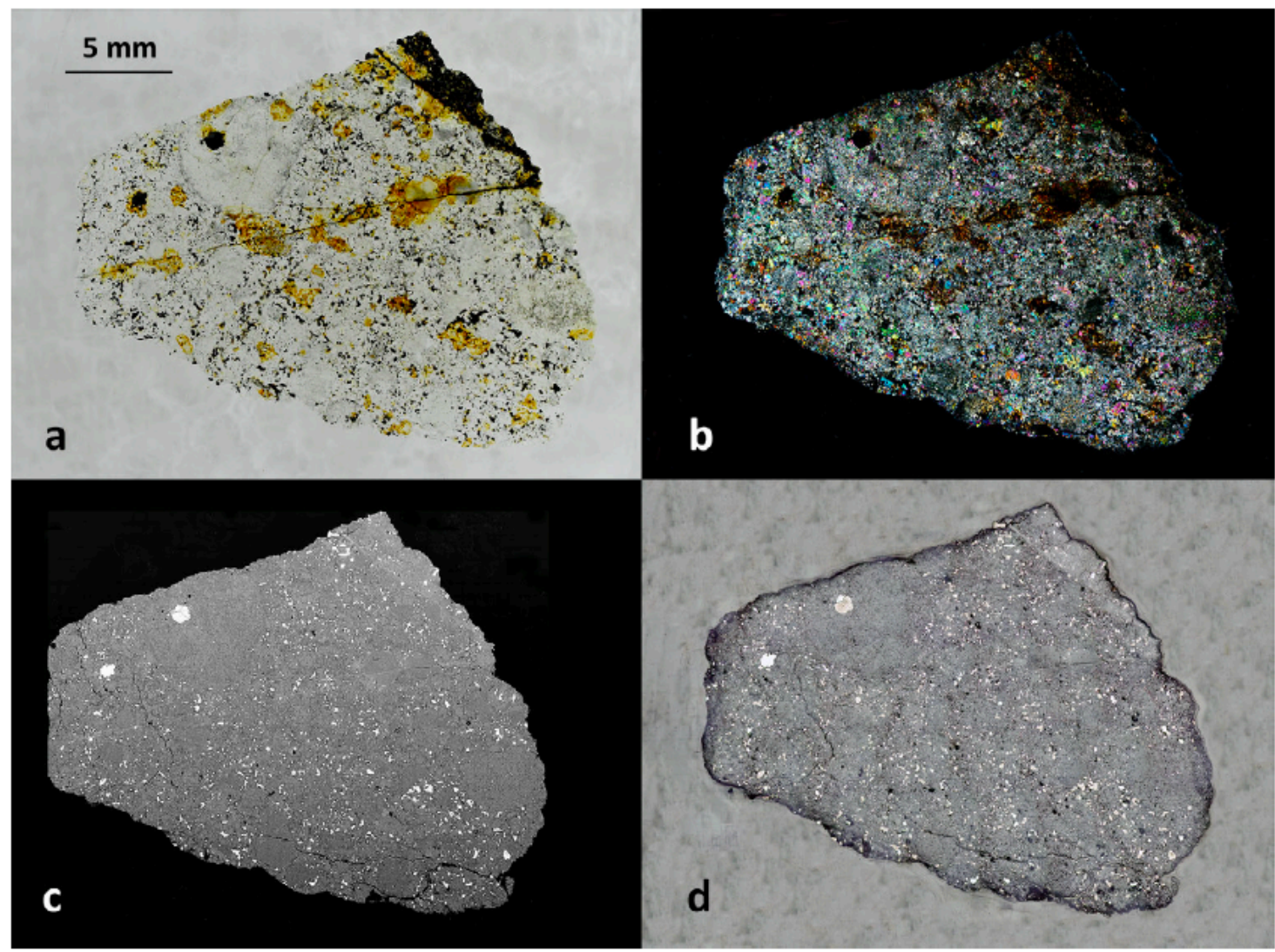

Figure 8. Optical microscope images of the thin section of the Barcelona meteorite obtained with transmitted light (a), cross-polarized light (b) SEM-BSE (c), and reflected light (d). 

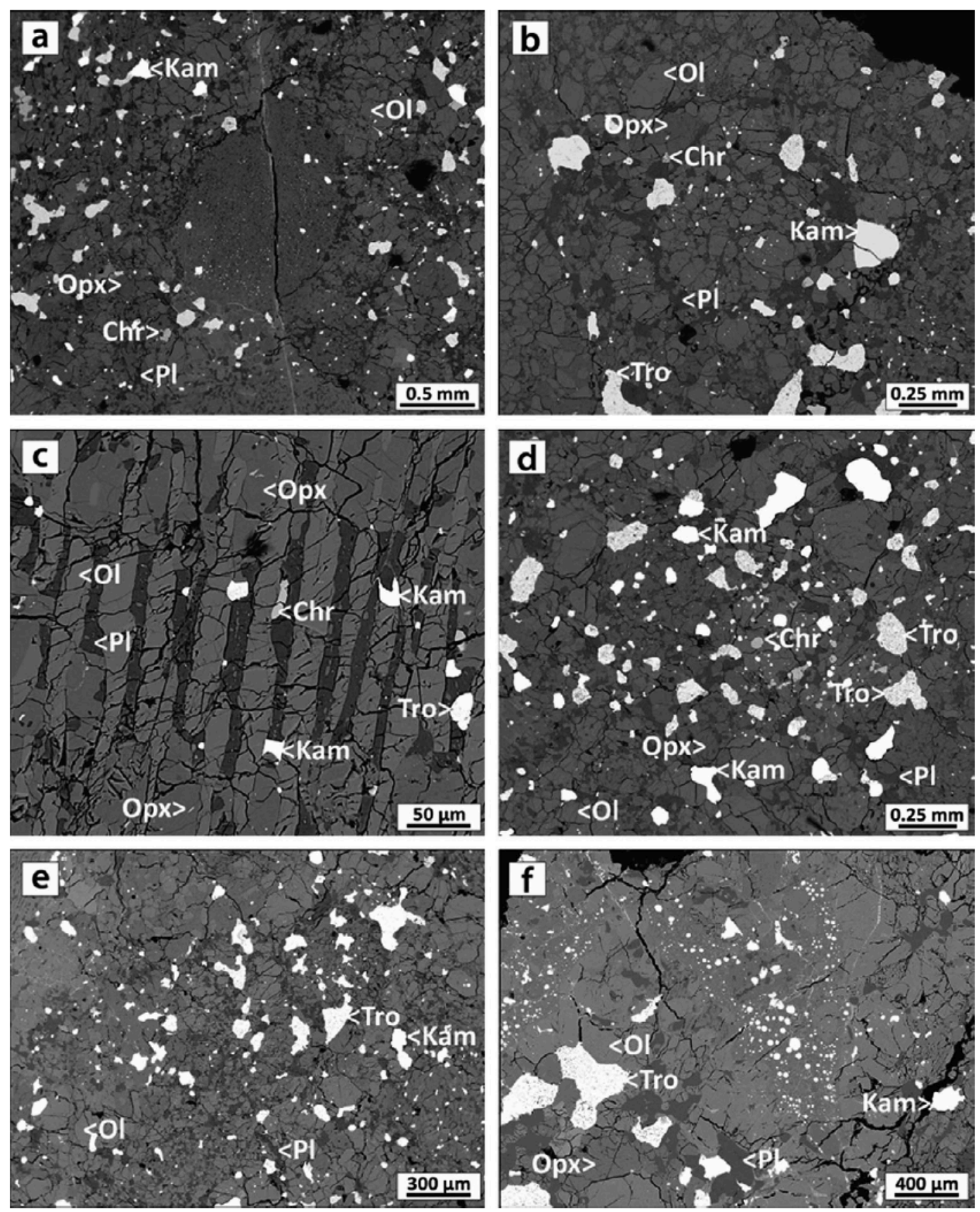

Figure 9. SEM (BSE) images of the Barcelona meteorite thin section. (a) Elongated fracture across an olivine-rich chondrule surrounded by the typical mineral association: olivine (OI), orthopyroxene (Opx), plagioclase (PI), kamacite (Kam) and chromite (Chr). (b) Poorly-defined olivine (OI) chondrule surrounded by troilite (Tro) and kamacite (Kam) and accessory orthopyroxene (Opx) and plagioclase (PI). (c) Typical elongated barred texture comprised of alternating bands of olivine (OI) and combined orthopyroxene (Opx) - plagioclase (PI). (d,e) Subhedral to anhedral troilite (Tro) and kamacite (Kam) grains associated with a silicate matrix formed by olivine (OI), orthopyroxene (Opx) and plagioclase (PI) with accessory chromite (Chr). (f) Quenched melt vein with metal blebs composed of an intergrowth of metal and troilite. 


\subsection{Mineral chemistry}

Table 1 shows the mean compositions of metal and sulfide phases as obtained by electron microprobe analysis. The composition of kamacite is $93.5 \pm 1.4 \mathrm{wt} \% \mathrm{Fe}, 5.5 \pm$ $1.6 \mathrm{wt} \% \mathrm{Ni}$ and $0.9 \pm 0.1 \mathrm{wt} \% \mathrm{Co}$, and that of taenite is $82.6 \pm 2.8 \mathrm{wt} \% \mathrm{Fe}, 16.3 \mathrm{wt} \% \mathrm{Ni}$ (range of $11.7-26.4 w t \%)$ and $0.7 w t \%$ Co (range of $0.3-0.8 w t \%)$. Tetrataenite is also present (Table 1). The composition of troilite is very homogeneous, $63.0 \pm 0.3 \mathrm{wt} \% \mathrm{Fe}$ and $37.0 \pm 0.2$ wt\% S. Table 2 shows the mean compositions of silicate phases and chromite as obtained by electron microprobe analysis. The olivine composition is Fa $25.8 \pm 0.2 \mathrm{~mol} \%$ (range of $25.4-26.8 \mathrm{~mol} \%$ ), the low-Ca pyroxene composition is Fs 21.7 $\pm 0.3 \mathrm{~mol} \%$ (range of 20.4-23.6 mol\%), Wo $1.4 \pm 0.2 \mathrm{~mol} \%$ (range of 0.9-1.9 mol\%), and the plagioclase composition is Ab $84.2 \pm 0.7 \mathrm{~mol} \%$ (range of $82.7-85.6 \mathrm{~mol} \%$ ), Or $5.6 \pm$ 0.5 mol\% (range of 4.4-6.7 mol\%). Figure 10 shows the chromite composition of the Barcelona meteorite along with mean values for $\mathrm{H}, \mathrm{L}$ and $\mathrm{LL}$ ordinary chondrites (Boschi et al. 2017, Bunch et al. 1967, Wlotzka 2005). All the EPMA data has been tabulated as a single file that is available as an electronic supplement.

Table 1. Mean compositions (wt\%) of metal and sulfide phases.

\begin{tabular}{ccccc}
\hline & Troilite & Kamacite & Taenite & Tetrataenite \\
\hline nr. of grains & 18 & 10 & 25 & 2 \\
$\mathrm{Si}$ & $<0.1$ & - & - & - \\
$\mathrm{Mn}$ & $<0.1$ & - & - & - \\
$\mathrm{Fe}$ & $63.0 \pm 0.3$ & $93.5 \pm 1.4$ & $82.6 \pm 2.8$ & $46.6 \pm 1.2$ \\
$\mathrm{Co}$ & $<0.1$ & $0.9 \pm 0.1$ & $0.7 \pm 0.1$ & 0.1 \\
$\mathrm{Ni}$ & $<0.1$ & $5.5 \pm 1.6$ & $16.3 \pm 3.1$ & $52.4 \pm 0.5$ \\
$\mathrm{P}$ & - & - & - & - \\
$\mathrm{S}$ & $37.0 \pm 0.2$ & $<0.1$ & $<0.1$ & - \\
Total & $100.3 \pm 0.4$ & $100.0 \pm 0.3$ & $99.6 \pm 0.6$ & $99.3 \pm 0.2$ \\
\hline
\end{tabular}


Table 2. Mean compositions (wt\%) of silicate phases and chromite.

\begin{tabular}{ccccc}
\hline & Olivine & Low-Ca pyroxene & Plagioclase & Chromite \\
\hline$n$ r. of grains & 36 & 25 & 20 & 28 \\
$\mathrm{SiO}_{2}$ & $38.1 \pm 0.7$ & $55.7 \pm 1.7$ & $66.0 \pm 1.7$ & $0.2 \pm 0.1$ \\
$\mathrm{TiO}_{2}$ & - & $0.17 \pm 0.08$ & - & $2.8 \pm 1.0$ \\
$\mathrm{Al}_{2} \mathrm{O}_{3}$ & - & $0.15 \pm 0.05$ & $21.1 \pm 0.6$ & $5.5 \pm 1.2$ \\
$\mathrm{Cr}_{2} \mathrm{O}_{3}$ & $<0.1$ & $<0.1$ & - & $56.1 \pm 1.6$ \\
$\mathrm{FeO}$ & $23.9 \pm 1.0$ & $14.5 \pm 0.3$ & - & $31.7 \pm 1.7$ \\
$\mathrm{MnO}$ & $0.5 \pm 0.1$ & $0.50 \pm 0.04$ & - & $0.55 \pm 0.13$ \\
$\mathrm{MgO}$ & $38.4 \pm 1.0$ & $28.9 \pm 3.4$ & - & $2.3 \pm 1.4$ \\
$\mathrm{CaO}$ & $<0.1$ & $0.7 \pm 0.3$ & $2.2 \pm 0.1$ & $<0.1$ \\
$\mathrm{Na} 2$ & - & $<0.1$ & $10.0 \pm 1.0$ & - \\
$\mathrm{K}{ }_{2} \mathrm{O}$ & - & - & $1.0 \pm 0.2$ & - \\
$\mathrm{NiO}$ & $<0.1$ & - & - & $<0.1$ \\
$\mathrm{CoO}$ & - & - & - & $<0.1$ \\
Total & $101.0 \pm 0.3$ & $100.7 \pm 0.7$ & $100.4 \pm 0.8$ & $99.2 \pm 0.8$ \\
End-member & $\mathrm{Fa}_{25.8 \pm 0.2}$ & $\mathrm{Fs}_{21.7 \pm 0.3}$ & $\mathrm{Ab}_{84.2 \pm 0.7}$ & \\
& & $\mathrm{Wo}_{1.4 \pm 0.2}$ & $\mathrm{Or}_{5.6 \pm 0.5}$ & \\
\hline
\end{tabular}
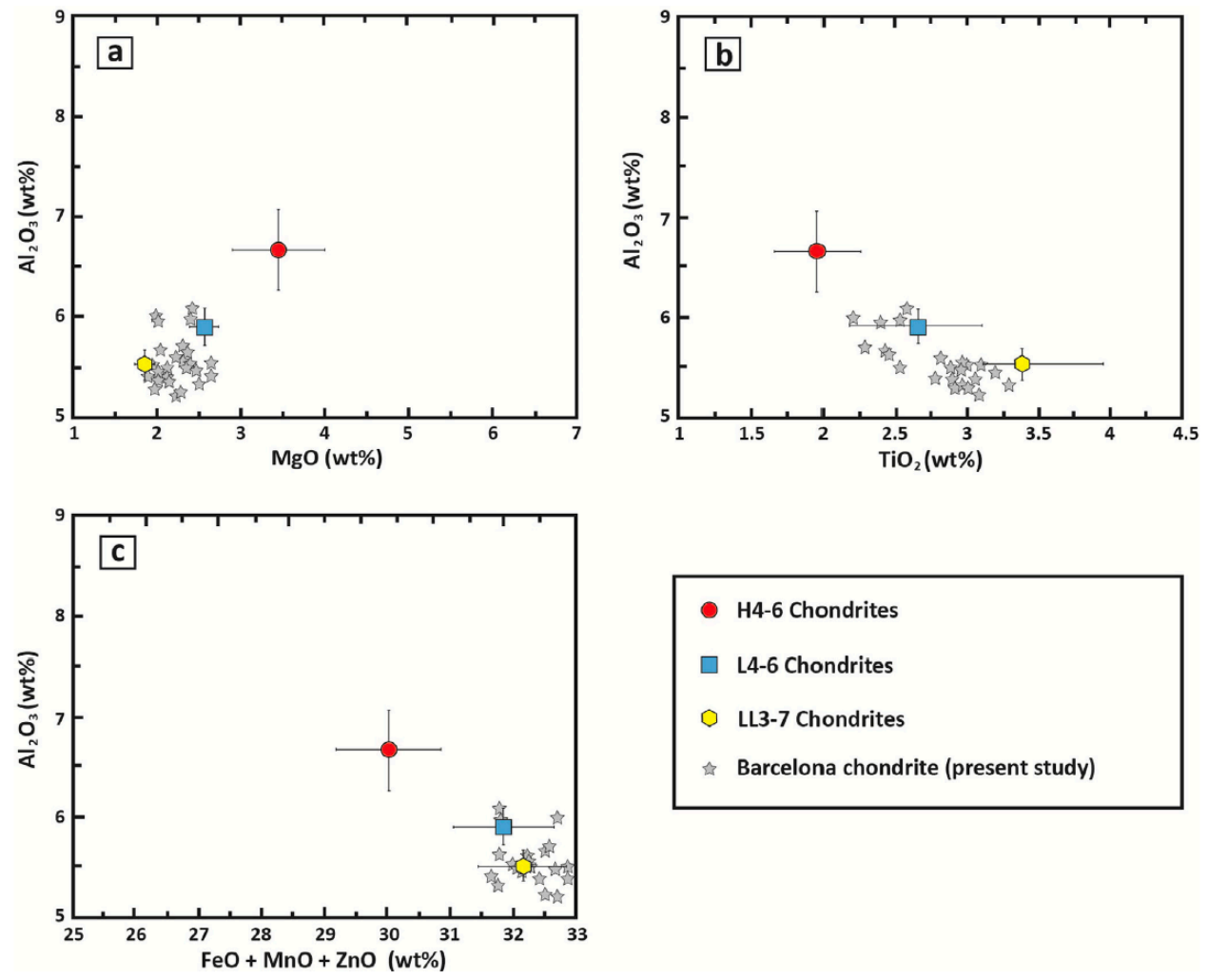

Figure 10. Plot of the chromite composition of the Barcelona meteorite along with mean values for $\mathrm{H}, \mathrm{L}$, and LL ordinary chondrites (Boschi et al. 2017). 


\subsection{Classification}

The chemical composition of olivine and low-Ca pyroxene, together with the Co content in kamacite and the total metal content of the meteorite, are in the range of Lgroup chondrites (Fig. 11) (Rubin 1990). Also, the plagioclase composition coincides well with the composition of $L$ chondrites (van Schmus et al. 1968). The homogeneity of the mafic silicate compositions, the definition of the chondrules, the occurrence of $>50 \mu \mathrm{m}$ plagioclase grains, the absence of diopside grains in the matrix and the recrystallized texture indicate petrologic type 6 (Van Schmus et al. 1967; Krot et al. 2014). The occurrence of weak mosaicism and sets of planar fractures in the olivine grains, as well as the occurrence of melt pockets with interconnecting veins indicate a shock stage of S4 (Stöffler et al. 1991). Some silicate staining is observed in both specimens (Figures 7 and $8 a$ ), but the absence of oxide rims around metal and troilite and hydroxide rims indicate a weathering grade of WO (Zurfluh et al. 2016).

Considering the original label conserved in the glass jar where the meteorite fragments were preserved and the time when the members of the Salvador family collected the Cabinet, it is very unlikely that the meteorites preserved could correspond to another meteorite fall in Catalonia. However, and for the sake of clarity, we have plotted in Fig. 11 the data corresponding to the other four known Catalan meteorites: Nulles fall in 1851 (Williams et al. 1985), Cañellas fall in 1861 (Casanova et al. 1990), Gerona find in 1899 (Casanova et al. 1990) and Garraf find in 1905 (Keil et al. 1986). Clearly, the Barcelona meteorite cannot be confused with any of them. 

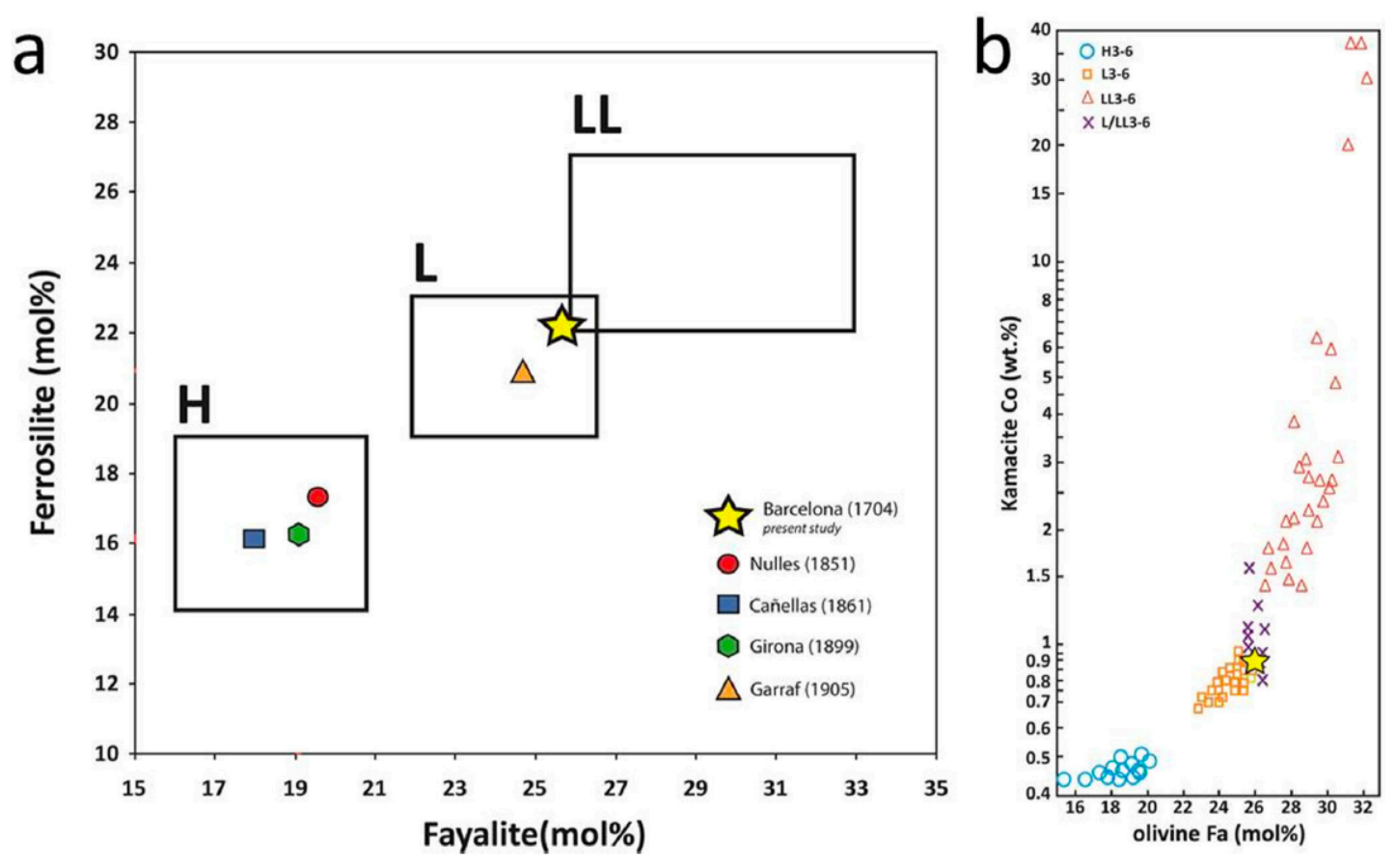

Figure 11. Plot of (a) the mean olivine and pyroxene compositions and (b) Co content in kamacite of the Barcelona meteorite along with mean values for H, L, and LL ordinary chondrites (Rubin 1990, Grossman et al. 2006). The olivine and pyroxene compositions of the other Catalan meteorites are included for comparison.

\section{Conclusions}

A meteorite fall occurred on Christmas Day of 1704, at about 17:00 h (UT) over Terrassa $\left(41^{\circ} 34^{\prime} \mathrm{N}, 2^{\circ} 03^{\prime} \mathrm{E}\right)$, about $25 \mathrm{~km}$ NW of the city of Barcelona. The meteorite fall was widely recorded in numerous historical documents. These testimonies reported that the meteorite originated as a fireball that was seen across the western Mediterranean in a clear sky, creating intense sound waves that were heard more than $100 \mathrm{~km}$ away. It was reported that several fragments weighing up to $5 \mathrm{~kg}$ fell in several places in Terrassa, separated by approximately $5 \mathrm{~km}$. Two of these fragments remained unnoticed in the Salvador Cabinet collection (Botanic Institute of Barcelona) for more than 300 years. In the present work we have disclosed their existence and have analyzed them. The specimens (49.8 and $33.7 \mathrm{~g}$ ) are very well preserved and are partly covered by a fresh fusion crust, indicating that they were recovered shortly after they fell. The meteorite is classified as a L6 chondrite. The Barcelona meteorite fall is a 
valuable example of the role of meteorites in history. It occurred during the War of Spanish Succession, one of the most important conflicts in the history of Europe, and it was interpreted as a divine sign and also used for propaganda purposes. The Barcelona meteorite is the third oldest preserved meteorite in Europe and the seventh in the world.

\section{Acknowledgments}

This work has been funded by the Institut d'Estudis Catalans, project PRO2018-S03. Jordi Llorca is a Serra Húnter Fellow and is grateful to ICREA Academia program and GC 2017 SGR 128. We thank Xavier Llovet and David Artiaga from the CCiTUB for their assistance in the EPMA and SEM analyses, respectively, and to Michela Romanini and Montserrat Domínguez from UPC for their assistance in the X-ray $\mu C T$ analyses. We would like to acknowledge the collaboration of Gerard Lucena, Marta Pérez-Azcárate and Jordi Cadevall from the MCNB for their work in the elaboration of the thin section and replicas of the meteorite fragments. We are grateful to Pauline Ernest (Open University of Catalonia) for her translations of the historical documents and assistance in English language editing. We also thank Adrian Brearley, Alan Rubin, Addi Bischoff, and Jonathan Lewis, who made some very helpful suggestions for improving the manuscript.

\section{References}

Alcoberro A. 2003. Memòria, història i pensament polític a l'exili austriacista. La crònica de la Guerra de Successió de Josep Plantí. Pedralbes: Revista d'Història Moderna 23:325-344.

Anonymous. 1704. Veridica relacion, venida de la civdad de Barcelona â esta Ciudad de Zaragoza, â 28 de Deziembre de 1704. Zaragoza: F. Revilla. 3 p.

Anonymous. 1705a. Clamors de Barcelona al tirà govern de Velasco. Barcelona: Imp. Joan Jolis. p. 1. Anonymous. 1705b. Mémoires pour l'histoire des Sciences \& des Beaux-arts, recueillies par ordre de Son Altesse Ser. Mons. Prince Souverain de Dombes. Trevoux: Impr. de S. A. S. p. 710-711. 
Anonymous. 1705c. Observations de Physique Generale. Histoire de l'Académie Royale des Sciences. Paris: Impr. Jean Boudot. p. 34-35.

Anonymous. 1706. Verdad desnuda armada de razón. Barcelona: R. Figueró. p. 14.

Anonymous. 1707. Exortació Cathòlica dirigida a la Nació Catalana. València. p. 27-28.

Anonymous. 1713?. Llabe profètica, theatro de pasiones y clarín castellano. Madrid: Imp. J Bot. p.2.

Arago D. F. J. 1855. Popular Astronomy. London: Longman, Brown, Green and Longmans. p. 162.

Aragonés E. 2008. El meteorit de Terrassa (25 de desembre de 1704). Terme 23:85-110.

Aragonés E. 2015. Bòlids i meteorits a Catalunya: una història (1700-1936). Notícies de Natura 28:1-32.

Aurell-Garrido J. "Informe del Meteorit Salv-8355 del Museu Salvador", 2015.

Belando N. J. 1740. Historia civil de España, successos de la guerra, y tratados de paz, desde el año de mil setecientos, hasta el de mil setecientos y treinta y tres. Madrid: Impr. M. Fernández. Vol. 1, p. 228.

Bolló J. 1717. Miscelánea científica ilustrada. Barcelona. p. 122.

Boschi S., Schmitz B., Heck P. R., Cronholm A., Defouilloy C., Kita N. T., Monechi S., Montanari A., Rout S. S., and Terfelt F. 2017. Late Eocene ${ }^{3} \mathrm{He}$ and Ir anomalies associated with ordinary chondritic spinels. Geochimica et Cosmochimica Acta 204:205-218.

Bruniquer E. G. 1916. Rúbriques de Bruniquer. Cerimonial dels Magnífics Consellers i Regiment de la Ciutat de Barcelona. Barcelona: Ajuntament de Barcelona. Vol. 5, p. 12-13.

Bunch T. E., Keil K., and Snetsinger K. G. 1967. Chromite composition in relation to chemistry and texture of ordinary chondrites. Geochimica et Cosmochimica Acta 31:1569-1582.

Camarasa J. M. 2018. Descripcions i notícies del gabinet Salvador en llibres de viatges, guies i altres documents impresos (1713-1895). Collectanea Botanica 37:e001.

Casanova I., Keil K., Wieler R., San Miguel A., and King E. A. 1990. Origin and history of chondrite regolith, fragmental and impact-melt breccias from Spain. Meteoritics 25: 127-135.

Castellví F. 1997). Narraciones históricas desde el año 1700 hasta el año 1725. Madrid: Fundación Francisco Elías de Tejada. Vol. 1, 722 p.

Constans L. 1950. Una crònica inèdita de la Guerra de Successió. Anales de Estudios Gerundenses $5: 73-112$.

Chladni E. F. F. 1826. Neue Beiträge zur Kenntniss der Feuermeteore und der herabgefallenen Massen. Annalen der Physik 1:45-60.

Faura i Sans M. 1921. Meteorits caiguts a Catalunya. Butlletí del Centre Excursionista de Catalunya $31: 270-288$.

Feliu de la Peña N. 1709. Anales de Cataluña. Barcelona: J.P. Martí, Vol. 3, p. 530.

Galí J. B. 1993. Llibre de notes dels hereus de Can Torres. Matadepera 1699-1824. Terme 8:29-37. 
Ginebra R. 2005. Guerra, pau i vida quotidiana en primera persona: el llibre de memòries de Bernat Puigcarbó de Muntanyola (s. XVI-XVII), el llibre de notes de Francesc Joan Lleopart de Vilalleons (s. XVII-XVIII), i els llibres de comptes i notes dels hereus Quatrecases de Pruit (16861812). Vic: Ed. Patronat d'Estudis Osonencs. p. 178.

Greg R. P. 1861. A Catalogue of Meteorites and Fireballs from AD 2 to AD 1860. Proceedings XIIIth Meeting of the British Association for the Advancement of Science. p. 48-118.

Grossman J. and Rubin A. 2006. White paper report for the Nomenclature Committee on the composition of olivine and pyroxene in equilibrated ordinary chondrites. https://www.lpi.usra.edu/meteor/docs/whitepaper.pdf

Ibáñez N. 2006. Estudis sobre cinc herbaris històrics de I'Institut Botànic de Barcelona. Ph.D. thesis, University of Barcelona, Barcelona, Spain.

Jordi R. 1982. Visita de boticas en Cataluña a principios del siglo XVIII (16-3-1710/10-4-1710). Circular Farmacéutica 274:111-139.

Keil K., Conrad G. H., King E. A., and San Miguel A. 1986. Petrology and classification of the Garraf, Spain chondrite. Meteoritics 21: 125-129.

Krot A. N., Keil K., Scott E. R. D. Goodrich C. A., and Weisberg M. K. 2014. Classification of meteorites and their genetic relationships. In Meteorites and Cosmochemical Processes, edited by Davis, A. M. Oxford: Elsevier. p 1-63.

Llorca J. 2004. El meteorito de la Guerra de Sucesión española. In Meteoritos y cráteres. Fragmentos de otros mundos que caen en la Tierra, Lleida: Ed. Milenio. p. 70-94.

Llorca J., Trigo J.M., and Vega S. 2002. The Meteorite Fall of 1704 at Barcelona (abstract \#5035). Meteoritics \& Planetary Science 37:A89.

Llorca J. and Vega S. 2004. El meteorit que va precedir la Guerra de Successió. Foc sobre Terrassa. Sàpiens 17:36-39.

Marvin U. B. 1992. The meteorite of Ensisheim: 1492 to 1992. Meteoritics 27:28-72.

Marvin U. B. 2007. Ernst Florens Friedrich Chladni (1756-1827) and the origins of modern meteorite research. Meteoritics \& Planetary Science 42:B3-B68.

Mas y Soldevila M. 1705. Diari des del mes de noembre del anÿ 1700, fins lo die 14 de octubre del anÿ 1705. Barcelona. p. 505.

Pons Guri J. M. 1959-60. Llibre de comptas i notas de Francisco Gelat, pagès de Santa Susanna, parròquia de Santa Maria de Pineda y Terma de Palafolls, bisbat de Gerona, comensat de escriura vuy, als 17 de setembre de 1698. [1698-1722]. Circular del Archivo Histórico y Museo Fidel Fita 2:3-15, 3:2-12, 6:11-14.

Rubin A. E. 1990. Kamacite and olivine in ordinary chondrites: Intergroup and intragroup relationships. Geochimica et Cosmochimica Acta 54:1217-1232. 
Sears D. W. and Sears H. 1977. Sketches in the history of meteoritics 2: The early chemical and mineralogical work. Meteoritics 12:27-46.

Solar J. 1705. Juizio sobre el celeste señal que sucedió en el dia 23. del mes de Noviembre deste presente Año 1705. que es la confirmación de aquel prodigioso Señal, que se vió en 25. de Deziembre de 1704. dia de la Natividad de Jesu-Christo Nuestro Señor, que tanto ha dado que discurrir á los curiosos. Barcelona: Impr. B. Giralt. 4 p.

Stöffler D., Keil K., and Scott, E. R. D. 1991. Shock metamorphism of ordinary chondrites. Geochimica et Cosmochimica Acta 55:3845-3867.

Van Schmus W. R. and Wood J. 1967. A chemical-petrologic classification for the chondritic meteorites. Geochimica et Cosmochimica Acta 31:747-765.

Van Schmus W. R. and Ribbe P. H. 1968. The composition and structural state of feldspar from chondritic meteorites. Geochimica et Cosmochimica Acta 32:1327-1342.

Ventalló J. 1879. Tarrasa antigua y moderna. Ensayo histórico. Terrassa: Impr. La Industrial. 330 p.

Williams C. V., Rubin A. E., Keil K., and San Miguel A. 1990. Petrology of the Cangas de Onis and Nulles regolith breccias: Implications for parent body history. Meteoritics 20:331-345.

Wlotzka F. 2005. Cr spinel and chromite as petrogenetic indicators in ordinary chondrites: equilibration temperatures of petrologic types 3.7 to 6 . Meteoritics \& Planetary Science 40:1673-1702.

Zurfluh F. J., Hofmann B. A., Gnos E., Eggenberger U., and Jull A. J. T. 2016. Weathering of ordinary chondrites from Oman: Correlation of weathering parameters with ${ }^{14} \mathrm{C}$ terrestrial ages and a refined weathering scale. Meteoritics \& Planetary Science 51:1685-1700. 